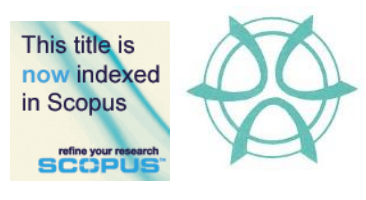

PLANNING MALAYSIA:

Journal of the Malaysian Institute of Planners

VOLUME 15 VOLUME 1 (2017), 369 - 376

\title{
YOUNG PROFESSIONALS' HOUSING AFFORDABILITY THROUGH HOUSING PREFERENCES IN KUALA LUMPUR AND A REVIEW ON THE MEANS-END CHAIN MODEL
}

\author{
Nor Suzylah Sohaimi ${ }^{1}$, Alias Abdullah ${ }^{2}$, Syafiee Shuid $^{3}$, \& Azila Ahmad Sarkawi ${ }^{4}$ \\ ${ }^{1,2,3,4}$ Kulliyyah of Architecture \& Environmental Design \\ INTERNATIONAL ISLAMIC UNIVERSITY MALAYSIA
}

\begin{abstract}
In a broad-spectrum, housing affordability issue is interrelated to young professional's well-being. However, this paper deliberated on young professional's housing preference in affordability context by taking into account some attributes of housing preference criteria. Data was obtained through questionnaire survey among 50 respondents aged between 25 and 35 years old and working in various professional fields in Kuala Lumpur. Descriptive analyses were then undertaken on the data from the survey. The study found that security criterion is the highest priority in housing preferences among the respondents. Having Wi-Fi is the second most important criterion. Additionally, this paper also provides a conceptual review on the Means-End Chain model.
\end{abstract}

Keyword: Housing preferences, affordability, young professional, Means-End Chain model

Date Received: $30^{\text {th }}$ April 2016

Date of Acceptance: $30^{\text {th }}$ October 2016 
Nor Suzylah Sohaimi, Alias Abdullah, Syafiee Shuid, \& Azila Ahmad Sarkawi

Young Professionals' Housing Affordability through Housing Preferences in Kuala Lumpur: Review on the Means-End Chain Model

\section{INTRODUCTION}

A house is beyond a shelter. It also plays important role in the design of psychological significance and economic well-being and individual wealth (Bourne, 1981). Due to this reason, a house has evolved from a mere shelter to a preference. Housing affordability among the young generation has become precarious circumstances. Youth Access (2007) views that young people struggle over housing affordability issues, as they are more likely to experience rented housing and homeless issues as compared to other groups. In dealing with housing preferences, young professionals also experience housing affordability limitation.

\section{RESEARCH OBJECTIVE}

Firstly, the study aims to identify young professionals' housing preferences through descriptive analysis. Secondly, the study aims to provide a conceptual review on the Means - End Chain (MEC) model.

\section{LITERATURE REVIEW}

\section{Young Professional}

In Malaysia, young professionals are referred to as graduates who have a Diploma or Bachelor Degree qualification. To elaborate the young professional cohort, age is another criterion that should be emphasised, although from international point of view, there is no consensus on the definition of youth based on age. The United Nations suggest that youth cohort refers to people aged 15 to 24 years while other studies have defined youth age is not later than 35 years old (Ministry of Youth Affairs and Sports India, 2014). On the contrary, from Malaysia's perspective, youth are those aged between 15 and 40 years. Because of the large range of the age, some scholars suggested the youth category is further divided into early youth comprises those 15-20 years old, middle youth 21-24 years old and late youth 25-35 years old (Hamzah et.al., 2007).

\section{Overview of MEC Model in Housing Preferences}

A review of housing affordability literature is considered voluminous. However, young professionals' affordability was not measured in these studies, but they were asked directly about affordable housing prices. When they make a decision to buy a house, they need to consider the housing preferences since it could be reflected on affordability.

Initially, MEC model has been applied to consider user's motives and found widespread application in marketing and consumer behaviour studies to identify consumer's value based on the choices made (Gutman, 1982). It has also been accepted broadly in various fields for its versatility (Zachariah \& Mohd Jusan, 2011). Even though MEC model adaptation in housing study is considered 
still at the infancy stage, it has been found to be a worthy method to identify housing preferences.

The MEC model was introduced by Gutman (1982), and its function is to understand value of product or service. The key point of MEC model is that consumer's option for achieving the desired consequences and minimalising the undesirable consequences. In a similar vein, some scholars posit that MEC is associated with attributes of good to achieving objectives and values (Coolen, Boelhouwer \& Kees, 2002). The "means" in the model are product or service in which consumers employ such as buying, consuming and reading. Meanwhile, "end" is valued states of being such as satisfaction, happiness, etc.

The MEC model structure associates attribute (A), consequences (C) and values $(\mathrm{V})$ as shown in Figure 1. The theory is accepted in the study of housing preferences as it depicts how a house buyer makes a decision based on housing attributes and the consequences of the usage of prospect housing and finally the buyer's value.

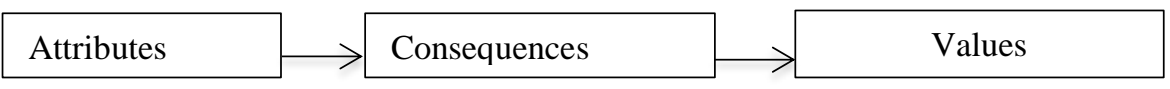

Figure 1 MEC Model Structure

Briefly, attributes in the chain explain the product or services' features, which some argue that attributes are signified as perceptible characteristics of a product (Veludo-de-Oliveira, Ikeda \& Campomar, 2006). Meanwhile, consequences are referred as effects of product use or, in other words, consumer's positive or negative responses towards product consumption (Lin, 2002). Values are viewed as life's drives, which motivate people to function in their actions (Gengler, Mulvey \& Oglethorpe, 1999). Adaption of the MEC model in measuring housing preferences has been extended from the original approaches by using quantitative method namely the laddering interview instead of depending merely on depth interview.

\section{METHODOLOGY}

The review of the MEC model was based on information from published previous studies, which was obtained through literature review. The housing preference of young professional, on the other hand, involve the use of questionnaire survey to obtain primary data from respondents. For the survey, young professionals aged between 25-35 years old (late youth) in various professional fields such as academic, architecture, engineering, banking and legal practice in Kuala Lumpur were given a self-administered questionnaire. The respondents were required to rate the housing attributes that they desire. The housing preferences attributes considered in this study comprises locational attributes which are access to the public transport and proximity to the places of occupation, shop and community services, parklands, and friends or family. Availability of facilities were also 
Nor Suzylah Sohaimi, Alias Abdullah, Syafiee Shuid,, \& Azila Ahmad Sarkawi

Young Professionals' Housing Affordability through Housing Preferences in Kuala Lumpur: Review on the Means-End Chain Model

considered including having a garden, shopping mall, Wi-Fi, self-service laundry, religious facilities, restaurant and sports facilities. Neighbourhood attributes such as a sense of community, security, privacy and quietness were also considered. A 5-point Likert scale, ranging from "Not Important" to "Critically Important" was used. Additionally, the affordable housing price or rent was also asked to identify their affordability.

The convenience sampling technique was applied in the survey. Initially, one hundred survey forms were handed out but only 70 were returned. Out of this 70,20 were incomplete, leaving only 50 questionnaires for analysis.

\section{RESULT AND ANALYSIS}

\section{Respondents Background}

Table 1 illustrates the respondents' characteristics in this survey. In terms of living quarters, the analysis found that a majority of the respondents (52\%) lives in an apartment, followed by terraced house (30\%) and other type of houses (10\%). Over half of them (62\%) are renting and about 24\% live in their parents' house. Only $10 \%$ of the respondents own a house. In addition, about $68 \%$ of respondents have three-bedroom home, regardless of renting or owned.

Table 1 Characteristic of Respondents

\begin{tabular}{lcc}
\hline & Frequency & Percentage \\
\hline Gender & 17 & 34 \\
Male & 33 & 66 \\
Female & & \\
Age & 19 & 38 \\
$25-30$ & 31 & 62 \\
$31-35$ & & \\
Marital status & 25 & 50 \\
Single & 24 & 48 \\
Married & 1 & 2 \\
Divorced & & \\
Education level & 24 & 48 \\
Bachelor Degree & 22 & 44 \\
Master Degree & 1 & 2 \\
Doctor of Philosophy & 3 & 6 \\
Other & & \\
Professional Level & 23 & 56 \\
Undergraduate degree & 25 & 4 \\
Postgraduate degree & 2 & \\
Professional qualification & & \\
\hline
\end{tabular}

\section{Housing Affordability}

In terms of affordable housing price, $41 \%$ of the respondents agreed that they can afford a house priced between RM150,001 to RM200,000. Meanwhile, 27\% of them felt that they can afford a house priced between RM200,001 to RM250,000, 
$8 \%$ can afford a house priced between RM250,001 to RM300,000. 10\% of them agreed that they can afford a house priced between RM300,001 to RM350,000. For a house priced more than RM350,000, less than $10 \%$ of the respondents felt that they can afford it. On the other hand, $4 \%$ of the respondents felt that they can only afford a house priced RM150,000 and below.

In terms of affordable rent, $35 \%$ of the respondents are willing to pay RM501 to RM700 rental monthly. The percentage became lesser as the rental rate becomes higher.

\section{Housing Preferences}

Almost all of the respondents (98\%) desired to buy a house. Only $2 \%$ preferred to rent. Additionally, $82 \%$ of the respondents intended to buy a house to live and only $18 \%$ intended to buy a house for investment. Based on current affordability, most of the respondents responded that they live in an apartment, regardless of owned or rented. However, they desire to stay in a terraced or semi-detached house in the future.

The respondents were also asked about their preferences for house size. $44 \%$ of them wished to have spacious house (more than 1,100 sq. $\mathrm{ft}$.), $28 \%$ preferred to stay in a house of $701-900 \mathrm{sq}$. ft. and $901-1100 \mathrm{sq}$. ft. respectively. Houses with less than 700 sq. ft. was not preferred by any of the respondents (Figure 2).

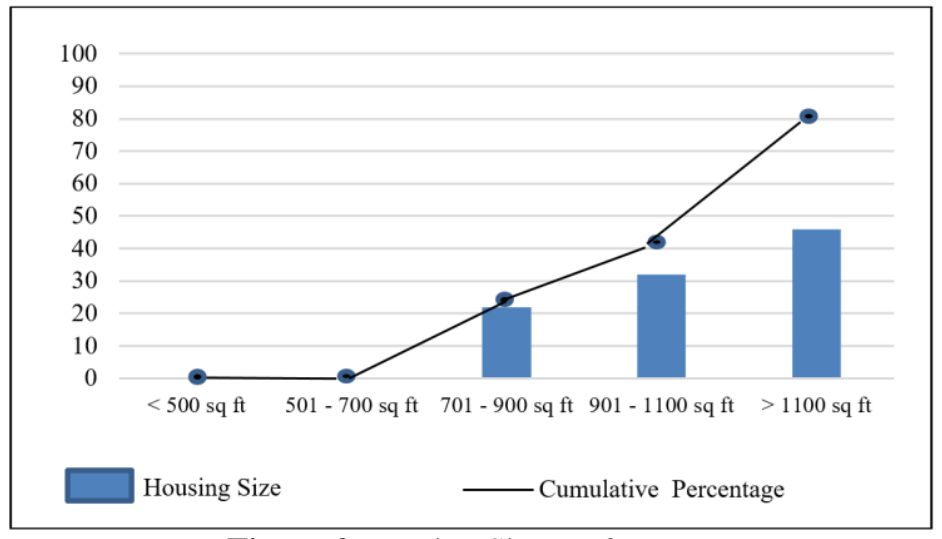

Figure 2 Housing Size Preferences

Additionally, the respondents were required to indicate the importance of housing criteria as illustrated in Figure 3. Number 1 to 16 in Figure 3 represent the house criteria. Whereas, number 0 to 4 is the axis to measure the degree of importance of the housing criteria, where four (4) is the highest degree of importance and zero (0) is the least degree of importance. In this analysis, the preference on the housing criteria is explained based on respondents' salary category. 
Nor Suzylah Sohaimi, Alias Abdullah, Syafiee Shuid,, \& Azila Ahmad Sarkawi

Young Professionals' Housing Affordability through Housing Preferences in Kuala Lumpur: Review on the Means-End Chain Model

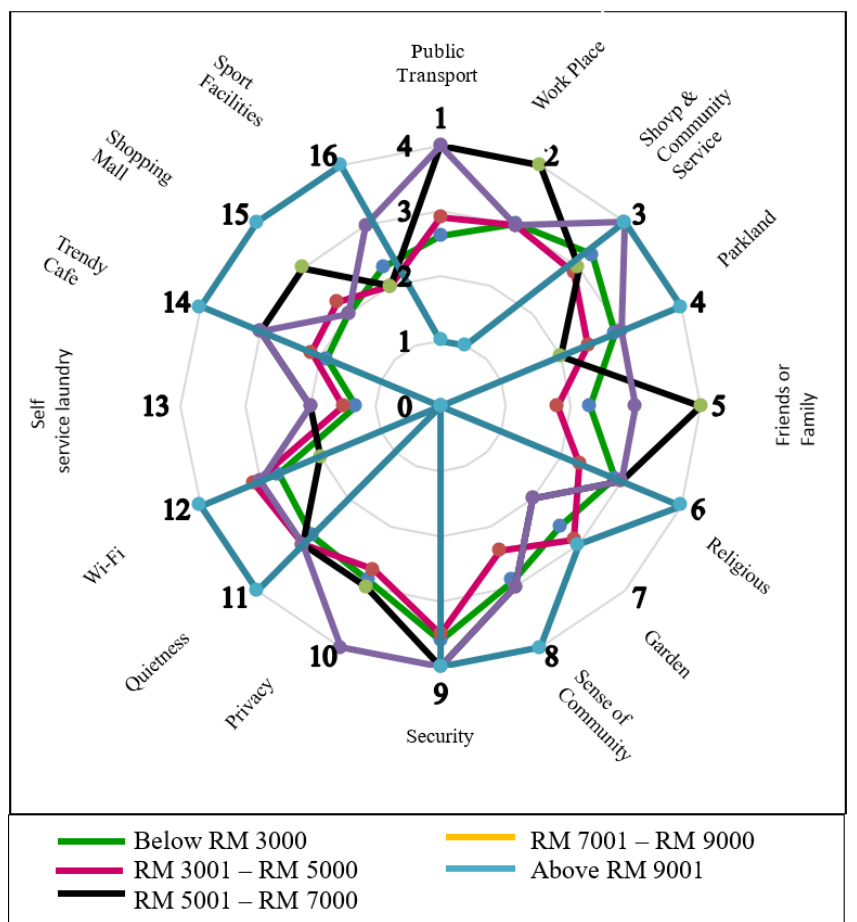

Figure 3 Importance of Housing Criteria

In overall, security criterion is the most important criterion among the respondents from all salary categories. However, respondents from three salary categories (RM5,001-RM7,000, RM7,001-RM9,000, and RM9,001 and above) have highest preference on security criteria at level 4 degree of importance while the respondents from other salary categories rate security at level 3.5 degree of importance.

Besides security, respondents also preferred houses with proximity to the shop and community service. Respondents with salary of RM7,000 and below have strong preference on this matter at about level 3 degree of importance, but those with salary of more than RM7,000 rated this criterion at level 4 degree of importance.

Availability of Wi-Fi was also important among the respondents. Respondents from all salary categories, except the RM5,001-RM7,000 category, indicated that $\mathrm{Wi}-\mathrm{Fi}$ is important to them at level 3 to 4 degree of importance. The importance of Wi-Fi was almost identical to the proximity to the workplace criterion, where most of the respondents also rated it as important criteria at level 3 to 4 degree of importance. Only respondents with salary of RM9,000 and above did not rated this criterion as important in choosing a house. 
PLANNING MALAYSIA:

Journal of the Malaysia Institute of Planners (2017)

Respondents in the highest salary category, which is RM9,000 and above, have high preference in many criteria such as proximity to shop and community service, parkland, religious facilities, sense of community, security, quietness, Wi-Fi, trendy cafés, shopping malls and sports facilities. They rated all these criteria at level 4 degree of importance.

Other criteria such as such as parkland and open space, religious facilities, quietness, a sense of community, privacy and proximity to public transport cannot be ignored as these are also needed by young professionals. All of these criteria averaged level 3 of the degree of importance. On the other hand, respondents rated facilities such as shopping mall, sports facilities, trendy cafés and garden or yard were only proved as moderately important house criteria. Other criteria such as proximity to friend or family, and self-service laundry were even less important, averaging about level 2 degree of importance.

\section{CONCLUSION}

In conclusion, this paper has explored the young professional's housing preferences. Young professionals have been chosen as the respondents since their contribution in human capital is considered significant and potentially affect the nation's economy growth. On that note, affordable housing is vital to improve the wellbeing of young professionals. Home is no longer perceived as only a shelter, but also importantly, with the right criteria it provides comfort and good quality of life.

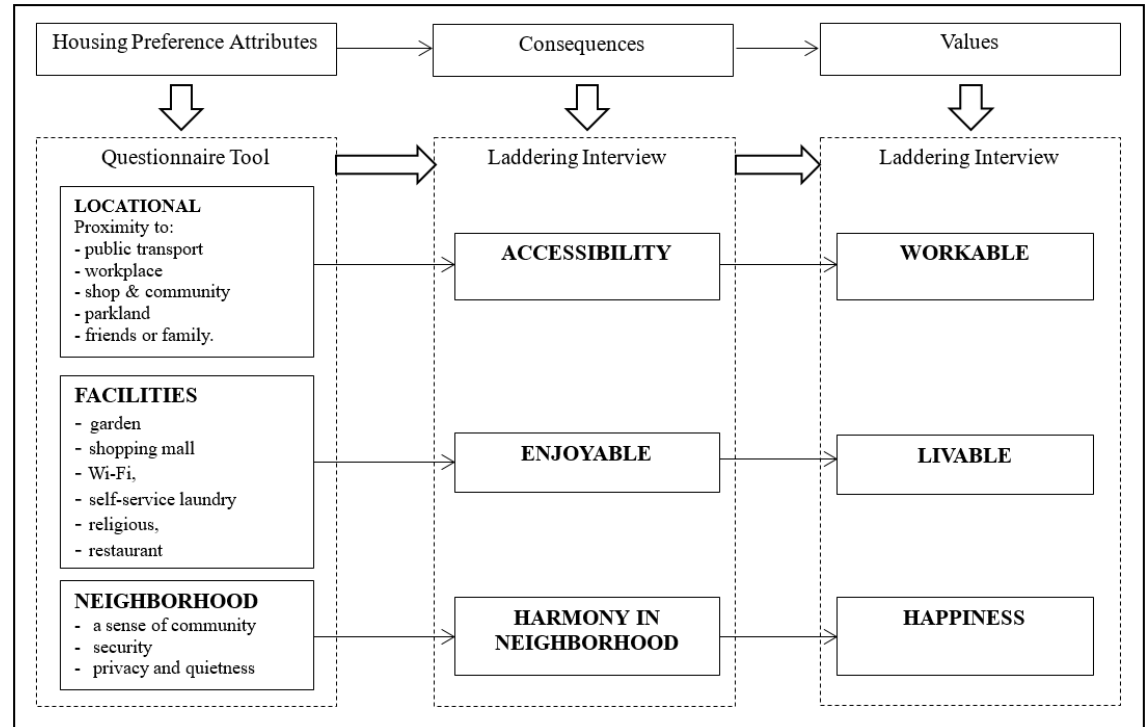

Figure 4 Proposed Extension of MEC Model on Housing Preferences Study 
Nor Suzylah Sohaimi, Alias Abdullah, Syafiee Shuid,, \& Azila Ahmad Sarkawi

Young Professionals' Housing Affordability through Housing Preferences in Kuala Lumpur: Review on the Means-End Chain Model

This paper also provided a brief review on the MEC model. It is suggested that the model be employed in further housing preferences research. Even though the MEC model was established quite a while ago, it is still considered to be at infancy level in housing research (Zachariah \& Mohd Jusan, 2011). Coolen's (2002) study on housing preference was probably the first attempt to adapt the MEC model to housing preference studies. The MEC model is also recommended to be expanded by applying the laddering technique, since the technique is useful for studying the complexities of consumer's cognitive structures. By expanding the model technique, it can be combined with survey question by asking the housing attributes, before proceeding with the laddering interview (Figure 4). Previous scholars also highlighted that the MEC approach is able to divulge the unseen choice behaviours (Zachariah \& Mohd Jusan, 2011). Therefore, the MEC model is well suited as a method for determining both objective and subjective features of housing environments and consumers' choice behaviours respectively.

\section{ACKNOWLEDGEMENTS}

The author appreciatively acknowledges the support from International Islamic University Malaysia (IIUM) and Ministry of Higher Education Malaysia, for the funding granted under the MyRa Incentive Grants Scheme (MRIGS).

\section{REFERENCES}

Bourne, L. S. (1981). The geography of housing. London: Edward Arnold Ltd.

Coolen, H., Boelhouwer, P., \& Kees, V. D. (2002). Values and goals as determinants of intended tenure choice. Journal of Housing and Built Environment, 17, 215-236.

Gengler, C. E., Mulvey, M. S., \& Oglethorpe, J. E. (1999). A means-end analysis of mother's infant feeding choices. Journal of Public Policy and Marketing, 18(2), 172-18.

Gutman, J. (1982). A means-end chain model based on consumer categorization processes. Journal of Marketing, 46, 60-72.

Hamzah, A., Krauss, S. E., Noah, S. M., Suandi, T., Juhari, R., Manap, J., \& Kassan, H. (2007). Muslim religiosity and personality assessment: prototype for nation building. Selangor: Institute for Social Sciences Studies (IPSAS)-University Putra Malaysia.

Lin, C. (2002). Attribute-consequence-value linkages: A new technique for understanding customer's product knowledge. Journal of Targeting Measurement and Analysis for Marketing, 10, 339-352.

Ministry of Youth Affairs and Sports India (2014). National Youth Policy India.

Veludo-de-Oliveira, T. M., Ikeda, A. A., \& Campomar. M. C. (2006). Discussing laddering application by the means-end chain theory. The Qualitative Report, 11(4), 626-642.

Youth Access (2007). Understanding young people's needs for advice, information and education on housing and related issues: an overview. Department for Communities and Local Government, UK.

Zachariah, Z. B., \& Mohd Jusan, M. (2011). Means-end chain model framework for measuring housing environment choice behavior. Journal of Civil Engineering and Architecture, 5(6), 535-546. 


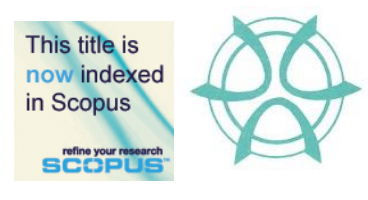

PLANNING MALAYSIA:

Journal of the Malaysian Institute of Planners

VOLUME 15 VOLUME 1 (2017), 377 - 388

\title{
LOCAL LEADERSHIP MODEL TOWARDS A RESILIENT CITY IN SEMARANG MUNICIPALITY
}

\author{
Lilin Budiati ${ }^{1}$ \\ ${ }^{l}$ EDUCATION AND TRAINING AGENCY OF CENTRAL JAVA
}

\begin{abstract}
This study assessed local leadership necessary for developing city resilience in the phase of more escalating, complicated and critical disaster phenomenon. The study departed from an assumption of the need for an effective and creative model of local leadership in order to transform risks into resilience, so that the city possesses a local capacity to develop Semarang as the resilient city. Leadership competency can be taught and trained by a leadership education and training under the Center for Education and Training of the Provincial Government of Central Java. Learning premise and practice of the leadership education and training in this study was formulated as follows: (1) Why was the leadership of Semarang Mayor unable to improve effectiveness of state internal bureaucracy towards city resilience?; (2) How was the model of local leadership necessary to develop Semarang city resilience?; and (3) What learning model of leadership education and training was effective to educate and to train the effective and creative bureaucratic leaders? Using a case study based qualitative approach, this study resulted in as the followings: (1) the mayoral leadership concerning hazard and city resilience issues was proven effective, but was unable to improve the effectiveness of the state internal bureaucracy due to structural conflict; (2) local leadership model related to disaster and city resilience issues that can be applied to Semarang Municipality is a congruent model with public-private partnership approach; and (3) the effective learning model that can be applied to the leadership education and training is a constructivist learning model with an intuitive approach.
\end{abstract}

Keyword: Local leadership, city resilience, constructivistic, leadership training and education

Date Received: $30^{\text {th }}$ April 2016

Date of Acceptance: $30^{\text {th }}$ October 2016 
Lilin Budiati

Local Leadership Model Towards a Resilient City in Semarang Municipality

\section{INTRODUCTION}

Semarang Municipality is a city familiar with disasters due to its geographical condition. The city is unique and specific, composed of coastal area at the "lower city zone" and highland at the "upper city zone". The coastal area is prone to such disasters as elevation of sea level, tidal flood, abrasion, and erosion, to mention some. Whereas, the highland has been identical with landslide, land movement, hurricane, drought, and flood due to high rainfall.

Previous studies (2009-2011) have proven that prior to 2010, effort from the municipal government of Semarang to overcome the disastrous conditions were technical, short-termed, and not integrated within medium- and long-term city planning. A study by Bisrie, Salim and Suroso (2011) revealed that Semarang became the coastal city in Indonesia with the most vulnerable of disaster. The Resilient City 2015 workshop identified shocks and pressures faced by Semarang. The determination of priority was done according to the 100RC tools by considering risk levels and probabilities. The workshop identified six major shocks currently faced by Semarang (Table 1):

Table 1 Disaster-Related Conditions in Semarang Municipality and Their Impacts

\begin{tabular}{|c|c|c|c|}
\hline No. & Shock & Major sub-mover & Main dimension \\
\hline 1. & Heavy flood & Ecosystem and asset management & Leadership and strategy \\
\hline 2. & Fire & Ecosystem and asset management & $\begin{array}{l}\text { Environment and } \\
\text { infrastructure }\end{array}$ \\
\hline 3. & Landslide & Ecosystem and asset management & Leadership and strategy \\
\hline 4. & $\begin{array}{l}\text { Dengue hemorrhagic } \\
\text { fever (DBD) }\end{array}$ & $\begin{array}{l}\text { capacity and facility of public } \\
\text { health service }\end{array}$ & Health and social welfare \\
\hline 5. & Drought & Ecosystem and asset management & $\begin{array}{l}\text { Environment and } \\
\text { infrastructure }\end{array}$ \\
\hline 6. & $\begin{array}{l}\text { Stability of raw } \\
\text { material supplies }\end{array}$ & $\begin{array}{l}\text { Provision, storage, and } \\
\text { distribution }\end{array}$ & Economy and social \\
\hline
\end{tabular}

Strategies and actions promulgated within the City Resilience Strategy had been performed under the co-ordination of the Working Group for the Resilience of Climate Change of Semarang Municipality, an ad hoc and multi-stakeholder team formalized by the Mayoral Decree of Semarang Municipality. The success of managing risk, adapting and mitigating disasters in a sustainable manner is affected by leadership, in particular the municipal leader (the mayor) and his or her municipal bureaucratic staff. Etzioni and Gross (1985) explain that a leader can be divided into two categories: formal and informal. Informal leaders are individuals with ability to control the others/followers by attribute, characteristic, and leadership capital derived from his or her personal strength. On the other hand, informal leaders are those having power due to his or her position, which, in turn, becomes the leadership requirement to influence the others, differing his or her from the "non leaders". 
Leadership is an art/way and/or ability to influence the others, to direct attitudes of subordinates or groups, to have particular abilities or proficiencies as required for obtaining organizational or group objectives (Kartono, 2003). Leaderships refers to three important aspects namely (1) leading process, (2) all leading activities or behaviours, and (3) ability to influence the others to perform particular duties determined by the leader for the group or organization objectives (Williams \& Cudjoe-Braithwaite, 2012).

In case of the current study, local leader is defined as a formal leader's leadership due to his or her strategic role and function in determining city (urban) development. By positional authority, formal leader is capable of mobilizing participation and collaboration of informal leaders and civil society to mutually develop local capacity for developing the city resilience.

The focal point of the local leadership comprises three leadership aspects namely (1) political leadership by the municipal leader (the mayor) and his or her bureaucratic leadership and staff, (2) professional and/or managerial leadership by professionals and/or higher education institutions, and (3) community leadership by community/civil society, non-government organization, autonomous institution and private sector leaders. Figure 1 illustrates the perspective of local leadership.

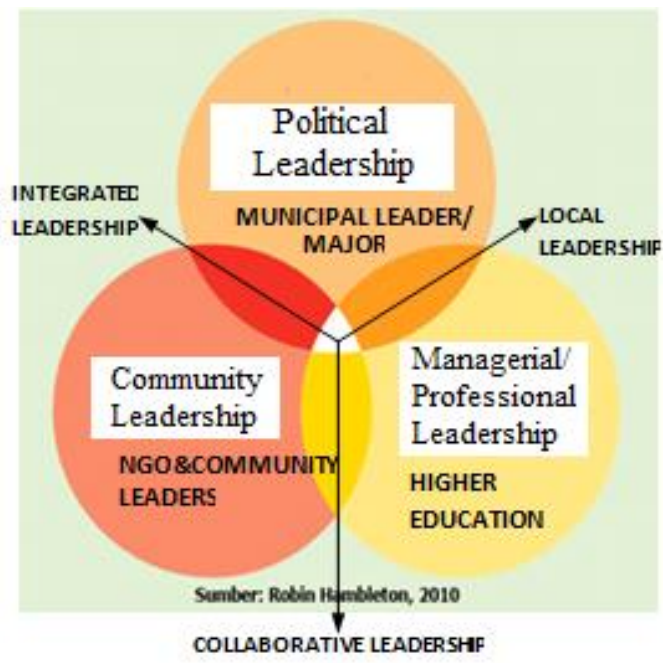

Figure 1 Local Leadership Perspective

Local leadership has an important role to develop local capacity to build a city resilience in order to decrease and to manage risk, to adapt, to give response, and to mitigate impact as well as to restore from damage and/or loss due to disasters. Towards this end, the local leadership is urged to integrate efforts of decreasing and managing the risk and adaptation of the disasters by planning the spatial development at short-, medium-, and long-terms. 
Lilin Budiati

Local Leadership Model Towards a Resilient City in Semarang Municipality

The purpose of developing the city resilience can only by achieved when the city is considered as a system where good urban governance is found.

The substantive meaning of the good urban development from the perspectives of disaster and city resilience are as follows: (a) the municipal government of Semarang becomes a conceptor, initiator, and implementor of policies on the local capacity building towards the development of a "resilient city" based on local identity, directing towards the actualizing "local identity", a situation that identifies localities of the city (geography, history, characteristics, and culture). These aspects become the foundation of the local capacity building; (b) local capacity building is achieved by productivity and growth in political, economic, social, and cultural aspects; (c) development efforts must allow participation of stakeholders and/or civil society at the stages of decision-making, planning, implementation, and evaluation; (d) development results, in forms of productivity and growth, must not be achieved by ignoring principles of equality and harmony in economic, social, and environmental aspects; and (e) urban system development must agree with the principles of good urban governance.

\section{RESEARCH METHODOLOGY}

This study applied a qualitative research method with a case study approach. The author assessed data with a comparative analysis, in a reflective manner, and followed it up with comparing interpretation translated into codes and categories.

\section{Research Design}

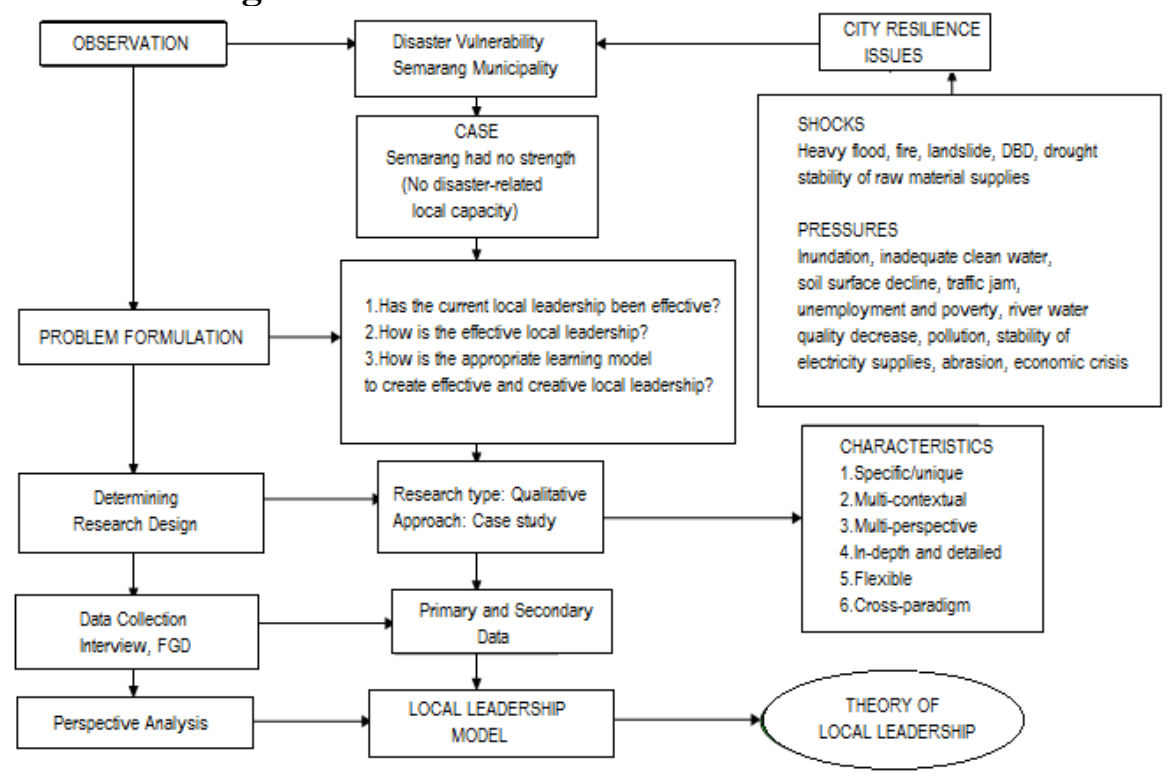

Figure 2 Research Design

Source: Remenyi et. al. (1998); CIPG elaboration by Budiati (2015) 
PLANNING MALAYSIA:

Journal of the Malaysia Institute of Planners (2017)

\section{Conceptual Framework}

A conceptual framework is a result of the author's thought about problems currently assessed and discovered to get the problem solution. It is a dialectical accumulation of vary activities, i.e. observation, seminar, workshop, and focus group discussion (FGD) concerning shocks and pressures faced by the city of Semarang due to hydro-meteorological and climate change disasters. The empirical reality observed was ecological damage footprints and vulnerability of the city towards the disastrous conditions, which had demanded the need for developing a sustainable, resilient city. Figure 3 illustrate the research conceptual framework.

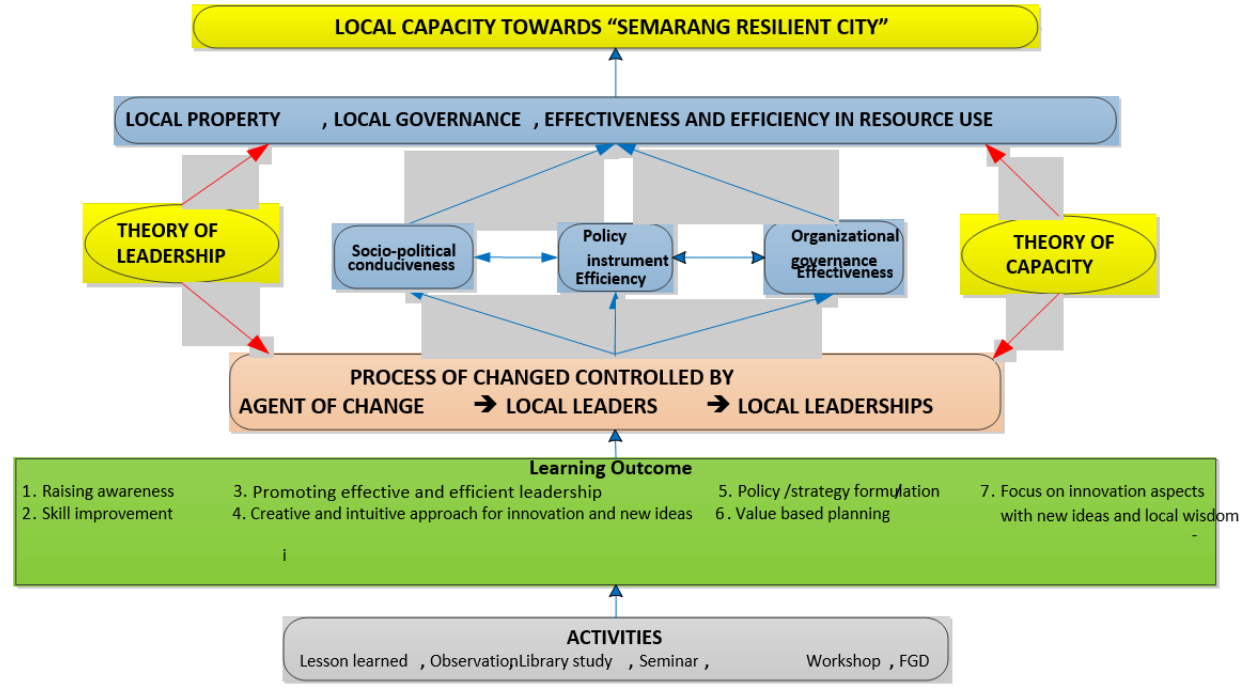

Figure 3 Conceptual Framework

\section{RESULTS AND DISCUSSION}

According to the Working Group for the Capacity of the Semarang Municipal RC Team (Municipal Government of Semarang, 2016), at sectoral level from the perspectives of disaster and city resilience, the effectiveness of the Semarang Mayor concerning the disaster (chronic shocks and pressures) had been in line with the reality, as the followings:

a) Evaluation and control of risk and adaptation to climate change impact

b) Financial and program aids from central government, international donors, and partner countries

c) Adaption and mitigation of acute shocks and chronic pressures (construction of folder, retention pond, critical area conservation, river stream restoration/west riverbank)

d) Development of strategy and roadmap for city resilience

e) Initiative of Semarang RC program 
Lilin Budiati

Local Leadership Model Towards a Resilient City in Semarang Municipality

\section{f) Establishment of Semarang Municipal RC Team}

At the larger scope, the FGD results proved that the leadership of the Semarang Mayor had not been effective to build the local capacity necessary for developing the city resilience, as proven by the following empirical facts:

a) Citizens of Semarang and the Performing Work Unit (SKPD) had not known and understood city resilience and/or Semarang RC programs

b) The implementation of the retention pond construction in Muktiharjo for overcoming flood and social aid project for poverty alleviation had not been accountable and been prone to corruption;

c) Programs/projects dealing with disaster control by the Municipal Disaster Prevention Agency (BPBD) and other concerned SKPDs were not integrated in a single package;

d) Lacking data and information of disasters. The available data were only understood by their makers.

e) "Alert Village" Program (Program Desa Siaga) promoted by the BPBD to build the preparedness and response of the community to the disasters was perceived as a subsidiary or grant project. Therefore, the BPBD was required to allocate funds by the community.

In case of BPBD of Semarang Municipality, the performance ineffectiveness is not merely caused by the poor influence and ability of the mayor to motivate BPBD to perform its principal duty and function effectively, but also due to internal gap because BPBD itself also lacks of instrumental efficiency by its structural construction. The BPBD structure is built upon Perka BNPB 3/2008 on the establishment of BPBD and Permendagri 46/2008 on Guide for Organization and Work of BPBD.

The FGD held on March 31, 2016 found that the ineffectiveness of the mayoral leadership for building the local capacity for developing a resilient city was due to the following factors:

a) The government tended to focus on policy or program during and post disaster. the policy only had a single purpose with a limited scope in particular disaster, such as flood. The implementation of the policy on flood in Semarang were as follows: early warning system, river sedimentation removal, road raising, and retention pond construction.

b) From the perspective of a city as a system and disaster context, the policy and program implemented by the municipal government of Semarang had not been effective because of lacking the good local/urban governance with the following principles: inclusion, productivity, locality, and sustainability. The program/project dealing with the flood was initiated by the government using the local budget (APBD) and/or the national budget (APBN) and had a single purpose to overcome problems related only to the flood. 
c) Social transformation where the citizens mobilize vertically and take part into the city planning did not occur. The mayoral policy flow was to-down and the aspiration and opinion flow of the citizens was bottom-up. Both flows were not integrated into a compromising point by mutual consent to make a decision of the city planning.

d) Gap between the effective mayor performance and ineffective local stage bureaucratic performance can be explained by the theory of situational leadership. According to Hersey and Blanchard (1998), the maturity of the subordinates (bureaucratic leadership under the mayor) is at the lowest level (unable and unwilling) to follow up and implement the Semarang RC program.

e) The position of the mayor as a political leader at the top of the hierarchy of the state bureaucratic structure at the local level, which manages the structural officials from the echelons IV to II, were generally career positions. This situation might lead to structural gap from authority distribution of the functions in the bureaucratic structure.

f) The establishment of the Semarang Municipal RC Team was ad hoc in characteristic. In other words, it was outside the bureaucratic structure. Thus, the Semarang RC program was unknown and lacking objective realities as the mutual agenda and goal.

Table 2 Ineffectiveness of Policy of Semarang Mayor

\begin{tabular}{cll}
\hline No. & $\begin{array}{c}\text { Cause of } \\
\text { ineffectiveness }\end{array}$ & \multicolumn{1}{c}{ Current condition of Semarang Municipality } \\
\hline 1 & $\begin{array}{l}\text { Practical politics } \\
\text { in planning }\end{array}$ & $\begin{array}{l}\text { Some policies of the Semarang Municipality were incremental, } \\
\text { incomprehensive, lacking preventive efforts. The government } \\
\text { tended to focus on policies or programs during or post disaster. The } \\
\text { comprehensive policy may result in good result or effect because of } \\
\text { rational thinking process supported by complete data or information. } \\
\text { It is expected to guarantee the sustainability of the policy. }\end{array}$ \\
\hline 2 & $\begin{array}{l}\text { Limited data and } \\
\text { information }\end{array}$ & $\begin{array}{l}\text { From the aspect of policy transparency, the government was not } \\
\text { active in socializing the policies on the city resilience the citizens } \\
\text { should have managed to access the information from either } \\
\text { conventional media or social media. For example, the policy on } \\
\text { license and surveillance of ABT in Semarang was relatively unclear. }\end{array}$ \\
\hline 3 & $\begin{array}{l}\text { Ego sector } \\
\text { Confusing programs caused multi-interpretative programs with } \\
\text { similar substances. }\end{array}$ \\
\hline $\begin{array}{l}\text { Programs/ } \\
\text { activities were } \\
\text { not aspiring, } \\
\text { participative, and } \\
\text { inclusive. }\end{array}$ & $\begin{array}{l}\text { A program or policy must be inclusive by involving and providing } \\
\text { opportunities to all stakeholders to give their opinions, complaints, } \\
\text { and to determine the role and contribution towards end result. } \\
\text { Implementation in Semarang Municipality still needed an } \\
\text { improvement of the citizens' active participation. } \\
\text { Private sector was expected to enlarge its role by co-ordinating with } \\
\text { the government and the community/civil society with an integrated } \\
\text { effort towards a much better policy implementation. }\end{array}$ \\
\hline
\end{tabular}


Lilin Budiati

Local Leadership Model Towards a Resilient City in Semarang Municipality

5 Poor monitoring The importance of monitoring and evaluation of the implementation and evaluation of a policy or program as the main indicator for finding out to which extent the program has been achieved, along with its obstacles and the solutions. The poor monitoring and evaluation became an obstacle for the Municipal Government of Semarang to implement its policies, such as that of dealing with Underground Water (ABT) license. The license had been strict by a prohibition at the red zone, but the monitoring and evaluation in practice must be actually performed to prevent violations.

6 Capacity of ad Institutional networks were not integrated in the planning process, as hoc institution evidenced by authority and program overlapping, causing the lacking focus of the program. A grand design should have been made available and mutually agreed by concerned parties, i.e. the government (Bappeda, BPBD, and concerned institutions), private, and community.

The Semarang Municipal RC Team had managed to develop an organizational structure, which composes of three local leadership, i.e. political leadership (the mayor), professional leadership (academics/higher education), and community leadership (civil society), as well as private sector, as illustrated by Figure 4.

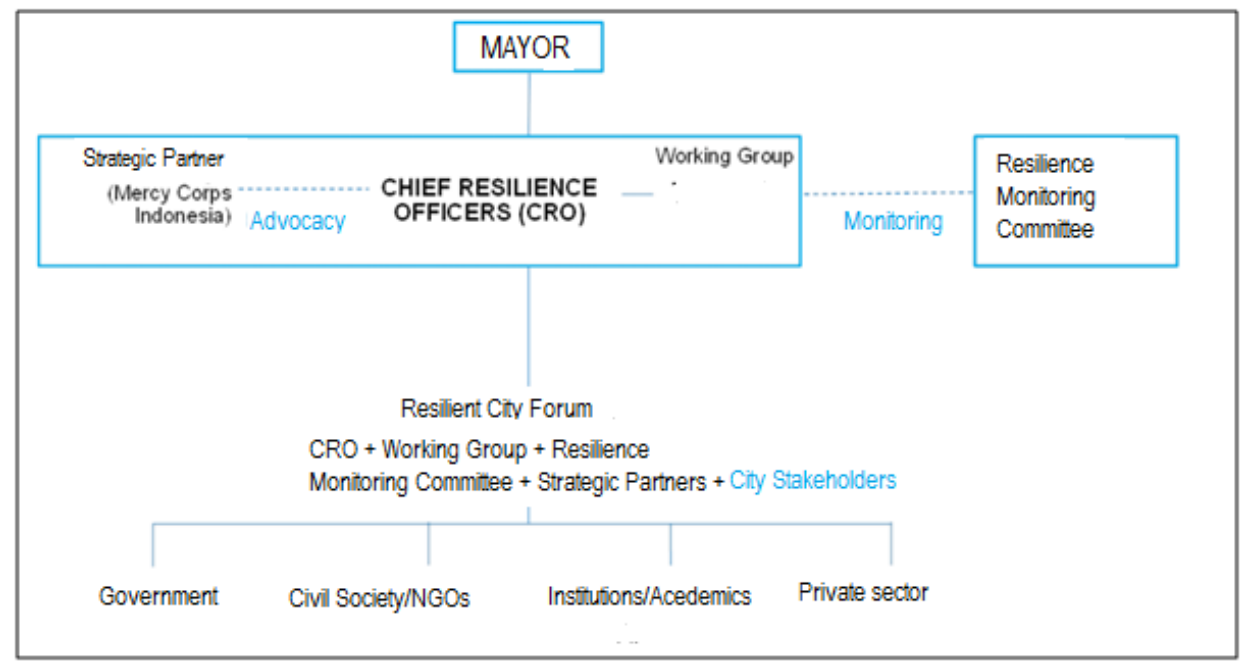

Figure 4 Organizational Structure of Semarang RC

The above organizational structure represents a policy networks at the program level with a public-private partnership. The problem will be how to make the program performance effective towards an optimal outcome. The main function of the local leadership, in particular the mayor, becomes a key factor to the successful program. However, the empirical reality proved the otherwise. 
Handayani (2015) found that the support of the municipal government of Semarang to the implementation of the $100 \mathrm{RC}$ program was not significant and "business as usual", without any innovation.

The involvement of the stakeholders through development plan meeting (Musrenbang) was ineffective and exposed by challenges. The developmental pattern tended to elitist, technical, partial and project oriented with short-term paradigm. In such condition, the local leader as the "agent of change" is necessary.

The $100 \mathrm{RC}$ contains formal (the government) and informal (nongovernment and civil society) organizational components. Therefore, a leadership model that integrates both component area needed. The formal organization of Semarang Municipal Government was structural (the functions were composed systematically in a hierarchical structure). Whereas informal organizations were functional (non-hierarchical structure). The difference in the organizational characteristics had created gap prone to counter-productive conflicts. The delineation of both components can be done by adopting a congruent model introduced by Nadler and Tushman (1997) modified by the program need.

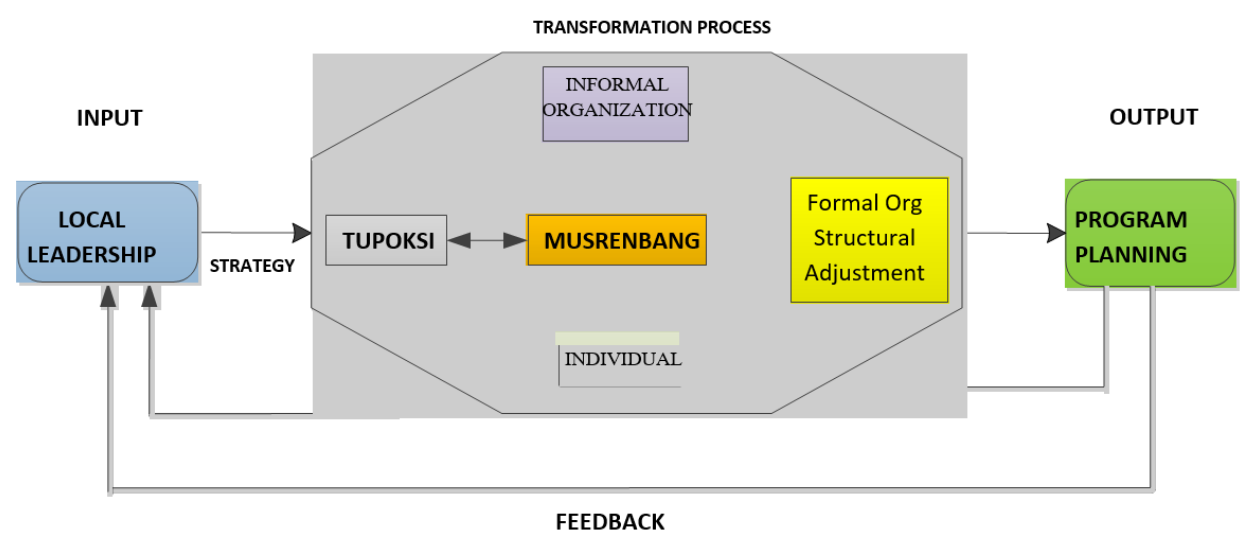

Figure 5 Local Leadership Model

At the input stage, there were components of local leadership, i.e. political leadership the mayor), professional leadership (professional organizations and higher education), and community leadership (civil society and NGOs). At the transformation stage, the strategy was transformed by the SKPD's principal duty and function as planned. At the output stage, work/program plans were established by a full support from the communities. The program/work plan implementation was monitored and evaluated in concert as feedback to the local leadership.

New pattern of Leadership Education and Training is a learning model based on experience by the State Administrative Agency (LAN) to replace the 
Lilin Budiati

Local Leadership Model Towards a Resilient City in Semarang Municipality

old pattern. The New Leadership Education and Training demonstrates a novelty that fulfilled the requirement as an innovation. The innovation was actualized as planned and systematically towards greater outcome, greater benefit, greater impact, cost effective, lesser risk, lesser resources, and greater performance. The novelty in the New Leadership Education and Training compared to the Old Leadership Education and Training is illustrated in Table 3 below:

Table 3 Novelty of New Leadership Education and Training Model

\begin{tabular}{lll}
\hline Dimension & $\begin{array}{l}\text { Old Leadership } \\
\text { Education and Training }\end{array}$ & $\begin{array}{l}\text { New Leadership } \\
\text { Education and Training }\end{array}$ \\
\hline Policy & $\begin{array}{l}\text { Output-oriented participant } \\
\text { competency }\end{array}$ & $\begin{array}{l}\text { Outcome-, integrity-, innovation- } \\
\text { and collaboration-oriented networks }\end{array}$ \\
\hline Paradigm & Administration & Public service \\
\hline Approach model & $\begin{array}{l}\text { State centred (by State } \\
\text { Administrative Agency, }\end{array}$ & $\begin{array}{l}\text { A combination between state } \\
\text { centred, pluralistic, and } \\
\text { transnational (intermestic) approach } \\
\text { models }\end{array}$ \\
\hline Provision & $\begin{array}{l}\text { AN). Domestic approach } \\
\text { model }\end{array}$ & $\begin{array}{l}\text { Off-campus education and training } \\
\text { available }\end{array}$ \\
\hline Learning & Off-campus education and & Constructivistic - experience based \\
& training unavailable & learning \\
\hline Change project & Behaviouristic, cognitivistic, \\
competence-based learning & Available \\
\hline Coach \& Mentor & Unavailable & Available \\
\hline Passing output & Unavailable & Less than 100\% \\
\hline Networks concept & 100\% & Available \\
\hline $\begin{array}{l}\text { Intensity of } \\
\text { collaboration between } \\
\text { institutions }\end{array}$ & Unavailable & High \\
\hline
\end{tabular}

Constructivistic learning model applied to the New Leadership Education and Training had been adequate. However, the implementation had not been effective as expected. The problem lied in the leadership substance as taught and trained by the education and training program. Towards the $21^{\text {st }}$ century, the leadership model contains new leadership values to answer the current threats and questions.

\section{CONCLUSION AND RECOMMENDATION}

Based on the findings, it can be concluded that:

a) The leadership of the Semarang Mayor related to disaster and city resilience had been effective but yet unable to improve the effectiveness of the state internal bureaucracy due to structural conflict.

b) The local leadership model that could be proposed for developing a resilient city towards the Semarang RC was a partnership-based congruent model, in which public and private sectors co-operate to implement a city resilience forum. 
PLANNING MALAYSIA:

Journal of the Malaysia Institute of Planners (2017)

c) The ideal learning model applied to the Leadership Education and Training was constructivist with an intuitive approach.

Recommendations to be proposed according to the findings of this study were as follows:

a) As a regulator, the municipal government of Semarang must re-evaluate its policies and programs for aiming targets in line with the actual needs. The municipal government must also perform periodical monitoring and evaluation over the policies and programs transparently for their sustainability.

b) As a facilitator, the municipal government of Semarang has to make effort to improve community awareness of the importance of the city resilience by socializing and updating issues, programs, achievements by means of official website, printed and electronic mass media, and social media networks.

c) There is a need for integration and co-ordination between formal organization (the government) and informal organizations, either internally (inside the administrative border of Semarang Municipality) or externally (areas nearby the city), in order to manifest local leadership for the successfully implemented city resilience program and policy.

d) Citizens of Semarang are expected to participate in activities dealing with decision-making, in particular those related to the city resilience, either in the planning, implementation, monitoring, or evaluation processes.

e) There is a need for mobilization and recognition of actual roles played by private sector by a co-ordination in planning and utilizing the CSR programs in integrated, transparent, and sustainable manners.

\section{ACKNOWLEDGMENT}

The author is indebted to all individuals with their own contribution towards the completion of this paper: Hendrar Prihadi, Herru Setiadhi, Bambang Haryono, Bobi Setiawan, Sigit Sumarhaen Yanto, Nugroho in Saputra, Wiwandari Handayani, Happy Santosa, Johan Silas, Prihadi, Jawoto, Pur, Joko, Lutfi and Mega. Special thanks go to Toton, Myrna, Arga, Mita, Nizar and Yaniz.

\section{REFERENCES}

Bisrie M. B.F., Salim A. W., \& Suroso D. S. A. (2011). Entry points. 2nd International Conference on "Cities at Risk", Taiwan, 11 - 13 April 2011.

Budiati, L. (2015). Diklat kepemimpinan pola baru dalam prespektif inovasi dan pembelajaran konstruktivistik. Jurnal Pembangunan Wilayah \& Kota, 11(2), 211-221.

Etzioni A., \& Gross E. (1985). Organizations in society. Englewood Cliff: Prentice-Hall Handayani W. (2015). Strategi Ketahanan Kota Semarang: Menuju Keselamatan Pangan, Air, dan Energi Melalui Adaptasi Perubahan Iklim. 100 Resilient Cities. 
Lilin Budiati

Local Leadership Model Towards a Resilient City in Semarang Municipality

Retrieved on October 17, 2016 from https://drive.google.com/file/d/ 0BxfH4L8MDpwhX1pGeE42bGF5c00/view.

Hersey P., \& Blanchard K. H. (1998). Management and organizational behavior. Englewood Cliff: Prentice-Hall.

Kartono K. (2003). Pemimpin dan kepemimpinan. Jakarta: PT Raja Grafindo.

Municipal Government of Semarang (2016). Laporan Kelompok Kerja (Pokja) Kapasitas Tim RC Semarang.

Nadler D. A., \& Tushman M. L. (1997). Competing by design: the power of organization architecture. New York: Oxford University Press.

Peraturan Kepala BNPB (2008). Pembentukan Badan Penanggulangan Bencana Daerah $(B P B D)$ No. 3.

Peraturan Menteri Dalam Negeri (2008). Pedoman organisasi dan tata kerja Badan Penanggulangan Bencana Daerah (BPBD) No. 46.

Remenyi D., Williams B., Money A., \& Swartz E. (1998). Doing research in business and management. London: Sage Production.

Williams G., \& Cudjoe-Braithwaite J. (2012). Electronic goal management. a case study in the water and sewerage authority. Retrieved on October 18, 2016 from http://unpan1.un.org/intradoc/groups/public/documents/undpadm/unpan049780 .pdf. 


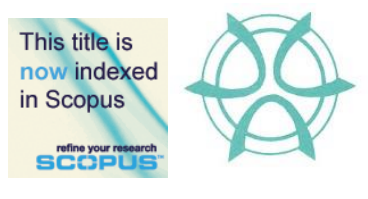

PLANNING MALAYSIA:

Journal of the Malaysian Institute of Planners

VOLUME 15 VOLUME 1 (2017), 389 - 396

\title{
SIDEWALK ACCESSIBILITY AT MELAKA'S TRADITIONAL STREETS FOR PEOPLE WITH DISABILITIES (PwDs)
}

\author{
Nor Haslina Ja'afar', Asiah Abdul Rahim², Nur Amirah Abd. Samad ${ }^{3}$, \& Che \\ Raiskandar Che Rahim ${ }^{4}$ \\ ${ }^{I}$ Faculty of Engineering and Built Environment \\ UNIVERSITI KEBANGSAAN MALAYSIA \\ ${ }^{2,3,4}$ Kuliyyah of Architecture and Environmental Design \\ INTERNATIONAL ISLAMIC UNIVERSITY MALAYSIA
}

\begin{abstract}
The accessibility of street as a social arena that fulfils the need for people with disabilities (PwDs) is an important consideration in the urban design of an area. With the rising number of PwDs in Malaysia, this aspect of street design is even more critical. This paper evaluates the accessibility level of sidewalk along Jalan Hang Jebat, Melaka to PwDs. On-site access audit simulation was carried out. Actual PwDs were engaged for the simulation. It was found that the sidewalk in inaccessible to PwDs due to presence of barriers and the design of the sidewalk itself. This paper suggest that the minimum requirement of MS1184:2014 must be implemented in the sidewalk design and the concept of 'shared space' can be adopted in the study area.
\end{abstract}

Keyword: Traditional street, accessibility, public space, access audit, people with disabilities (PwDs).

Date Received: $30^{\text {th }}$ April 2016

Date of Acceptance: $30^{\text {th }}$ October 2016 
Nor Haslina Ja'afar, Asiah Abdul Rahim, Nur Amirah Abd. Samad, \& Che Raiskandar Che Rahim

Sidewalk Accessibility at Melaka's Traditional Streets for People with Disabilities (PwDs)

\section{INTRODUCTION}

In urban design, street is an indispensable element in shaping a city. Lynch (1960) identifies street as 'path', which is one of the main elements of urban design. The importance of street can be seen from its appearance and its function as 'public open space' where it becomes a major node as an arena for various social activities such as relaxing, walking and chatting. Important streets generate their own individual character, which are mainly evident in old and traditional cities and towns (Abdul Rahim et al., 2014; Sulaiman, Shamsuddin \& Anwar, 2007; Bashiti \& Abdul Rahim, 2015).

Streets should also cater for the people with disabilities (PwDs). This is to promote similar level of accessibility to PwDs as to the general public. The consideration of PwDs' needs in street design is even more critical now, especially when the statistics from the Jabatan Kebajikan Masyarakat (Social Welfare Department) show an increasing trend in the number of PwDs in Malaysia (Bashiti \& Abdul Rahim, 2015). Similarly, Ja'far (2015) and Mohd Hussain et al. (2016) also state that the number of application for PwDs cards/passes in Malaysia is also increasing.

Abdul Rahim et al. (2014) propose that a sustainable design for accessibility should be considered in all of our physical development in order to make our cities world class. Accessibility in the built environment is increasingly relevant to Malaysia, not only to prepare for the ageing population and PwDs, but also for the whole population at large. In order to understand the best way to include the widest range of users it is necessary to recognise the range of abilities that must be served and hence to be able to prioritise their different needs (Harisson \& Dalton, 2013). Universal Design, having moved on from 'barrierfree' design, embraces more diverse needs than just providing for people with disability and recognises that in everyone's life course various forms of disability will be experienced, with differing degrees of seriousness. Perhaps one of the greatest advantages of adopting universal design principles is that they are inclusive of everyone, and not just providing for 'special needs' users or thinking merely of a 'barrier-free' environment.

In a more local context, Mohd Hussain et al. (2016) agree that the needs of PwDs have received attention from all parties since their number keeps increasing year by year. It is thus vital to provide proper planning and design guidelines to ensure that this group of people have the opportunity to access the environment (Ja'afar, 2015). Moreover, improved accessibility enhances the value of the built environment, thus creates a place or street that facilitates the people to have a better quality of life (Kose, 2014).

It is important that street environment, especially of the traditional streets, is accessible to all group of people including PwDs. Traditional streets are places of legacy. By having access to the streets, their legacy would be enjoyed and experienced by the people including PwDs and also tourists. Thus, 
PLANNING MALAYSIA:

Journal of the Malaysia Institute of Planners (2017)

this paper analyses the level of accessibility for PwDs to sidewalk of a traditional street design by referring to the minimum design requirements provided in Malaysian Standards MS1184:2014.

\section{METHODOLOGY}

Jalan Hang Jebat, which is located in the Historical City of Melaka, was selected as the study area. The Historical City of Melaka is one of the heritage site listed under the UNESCO World Heritage Sites. The Jalan Hang Jebat is a popular street in the City, which is frequented by locals and tourists alike. The street is lined with old shophouses on both sides. Sidewalks separate the street from the shophouses.

Data was obtained through access audit simulation, in which actual PwDs were employed to conduct the simulation on-site. Access audit is an examination of an existing building, including its facilities and services, against pre-determine criteria to assess its usability. The main objective of access audit is to study the accessibility level of a place (in this study, Jalan Hang Jebat) in order to aid the planning, design and improvements so that the objective of inclusive and universal use may be achieved (Mohd Hussain et al., 2016; Jabatan Kebajikan Masyarakat, 2014).

The simulation was carried out with actual disabled persons from three categories; elderly (including frail person), visually impaired and mobility impaired persons. These three categories were selected because they are the most significant category of the PwDs (Harrison \& Dalton, 2013; Shamsuddin \& Sulaiman, 2008). The objective was to test how well the outdoor street environment performs in terms of access and ease of use by these groups of users. Six PwDs were engaged for the simulation, with two PwDs per category. They are well trained in conducting access audit and simulations identify the types of barriers and dangers to PwDs in an area that may be unforeseen by urban designers, architects and city planners.

Checklist form was pre-prepared and used during the audit simulation. Elements of accessibility that were observed included curb cuts, tactile walking surface indicator (TWSI), pedestrian crossing and general obstructions. All identified problem areas were photographed as evidence and used in data analysis. Consequently, semi-structured in-depth interviews were conducted with the participants of the audit (the six PwDs) to gain information on their perceptions towards the accessibility level of the study area. Data from the simulations were compared to the Malaysian Standards MS1184:2014 in order to identify the level of accessibility. Colour codes were used to denote access level of the study area: (i) red (inaccessible), (ii) yellow (moderately accessible) and (iii) green (accessible). These approaches have been used by other researchers in conducting access audit simulation such as Zen, Abdul Rahim \& Abu Bakar (2012), and Ja'afar, Sulaiman and Shamsuddin (2012). 
Nor Haslina Ja'afar, Asiah Abdul Rahim, Nur Amirah Abd. Samad, \& Che Raiskandar Che Rahim Sidewalk Accessibility at Melaka's Traditional Streets for People with Disabilities (PwDs)

\section{RESULTS}

One of the main outputs of the access audit was a layout plan of the study area indicating the accessible routes along the Jalan Hang Jebat. For the study area, five main pit stops were identified along the street (Figure 1). The destination to each point was analysed, measured and marked. The results of the access audit are as in Table 1 below.

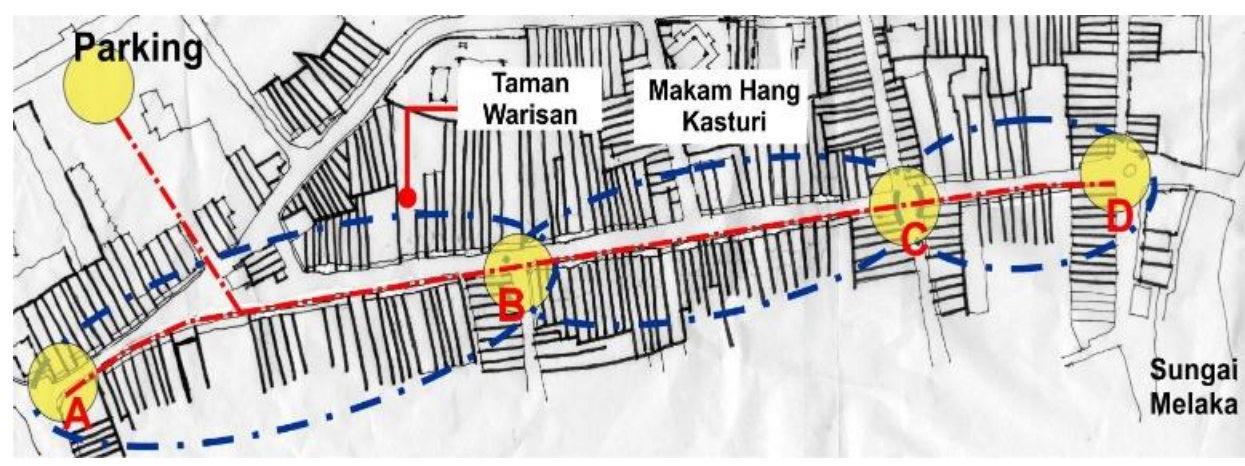

Figure 1 Journey of PwDs Base on 5 Main Stations

Table 1 Sidewalk Accessibility at Jalan Hang Jebat to PwDs

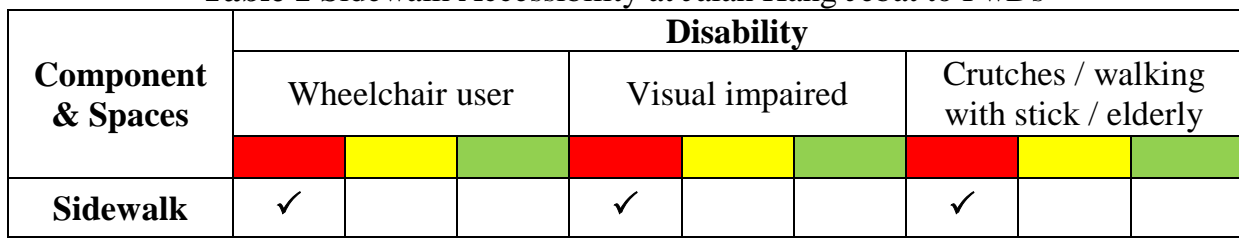

Legend:
\begin{tabular}{|l|l|}
\hline Level of Accessibility & Colour Code \\
\hline Accessible & \\
\hline Moderately accessible & \\
\hline Inaccessible & \\
\hline
\end{tabular}

Based on the access audit simulation, several obstructions were identified. It was found that the location of street lamps and vehicle that were parked on the sidewalk have obstructed the movement of PwDs (Figure 2) especially the wheelchair users and the visually impaired persons. According to the PwDs, "The location of lamp post in the centre of sidewalk obstructs the movement of people, especially the PwDs. There are also vehicles parked on the sidewalk and this irresponsible behaviour has created difficulties for people to walk along the sidewalk, especially PwDs. I think people who illegally parked their vehicles should be penalised."

Moreover, poorly designed and poorly maintained sidewalk also posed difficulties to the visually impaired persons and the wheelchair users (Figure 3). Poor design includes irregular width of the sidewalk, especially the portion where 
PLANNING MALAYSIA:

Journal of the Malaysia Institute of Planners (2017)

the sidewalk is too narrow. Width of sidewalk is also affected by peddlers and shop owners using the sidewalk to display their merchandise. Poor maintenance include broken surface of the sidewalk and missing tiles from the sidewalk surface.

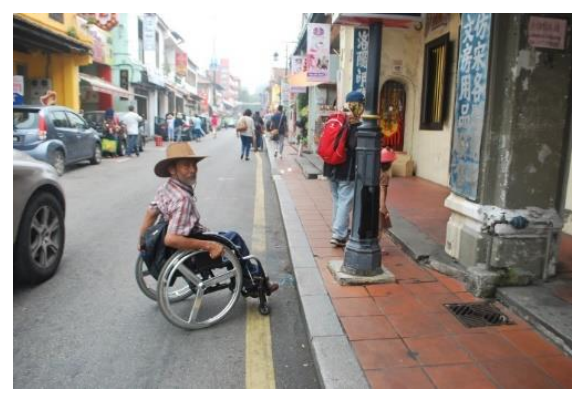

Figure 2.1 Obstructive Elements Along The Sidewalk: Lamp Post

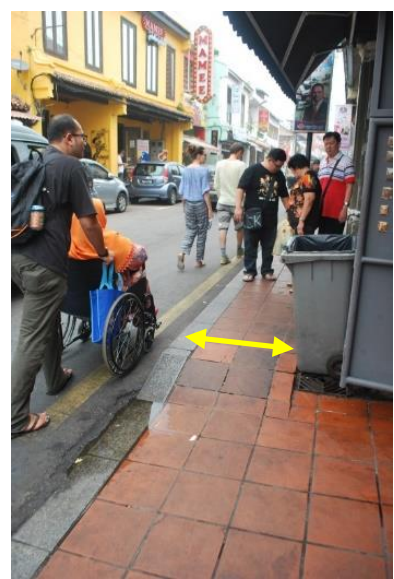

Figure 3.1 The Width of Sidewalk is Narrow at Some Locations

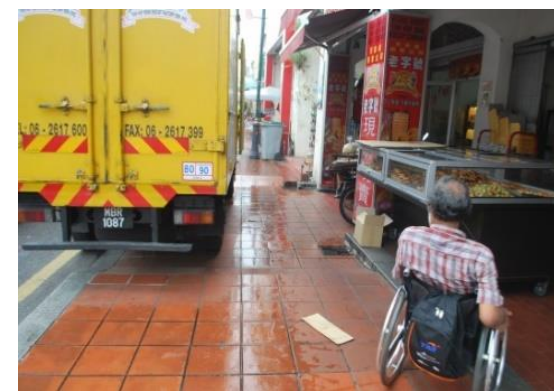

Figure 2.2 Loading Activities Obstructing the Accessibility of Sidewalk Especially for Wheelchair Users and Visual Impaired

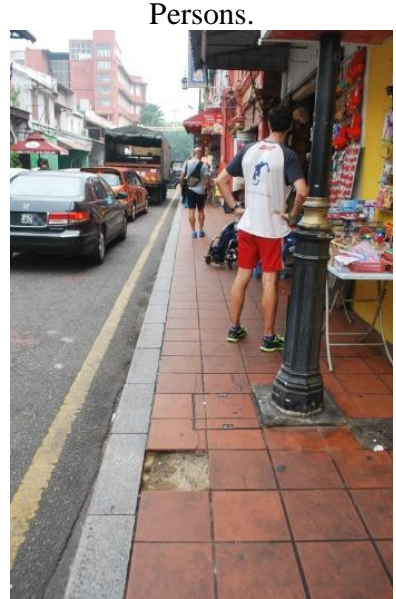

Figure 3.2 Poor Maintenance of Pavement Surface Create Barriers for PwDs

\section{RECOMMENDATIONS}

The information emerged from the access audit simulation indicates that the overall level of accessibility for PwDs at Jalan Hang Jebat is poor (inaccessible) especially for wheelchair users and visual impaired persons (Table 1). Thus, this paper recommends that the universal design approach based on the minimum requirements of the MS1184:2014 is implemented in the study area.

According to MS1184:2014, the clear minimum width of sidewalk should be $1500 \mathrm{~mm}$ (Department of Standards Malaysia, 2014) (Figure 4). Therefore, this paper suggests that the street lamps should be relocated away from 
Nor Haslina Ja'afar, Asiah Abdul Rahim, Nur Amirah Abd. Samad, \& Che Raiskandar Che Rahim Sidewalk Accessibility at Melaka's Traditional Streets for People with Disabilities (PwDs)

the sidewalk. At the same time, strict enforcement of traffic rules must be implemented to penalise and discourage people from parking their vehicles on the sidewalk.

The narrow width of sidewalk also obstructing the movement of the PwDs. One of the reason of narrow sidewalk in the study area is because of limited area. Thus, it is recommended that in cases where sidewalk width cannot be provided at the minimum of $1500 \mathrm{~mm}$, then sidewalk should not be provided at all. Instead, the concept of 'shared space' can be implemented where movement priority is accorded to pedestrians (Figure 4). Previous research shows that motor vehicles will slow down in shared space area because drivers will have to be aware of the pedestrian movement (MPMBB, 2010). In some cases, the 'shared space' can be transformed from street into pedestrianized area with limited vehicle access.

Other measures to improve sidewalk accessibility in the study area to PwDs must also be implemented. These include regular maintenance of the sidewalk and the restriction to shop owners and peddlers to use the sidewalk to display their merchandise.

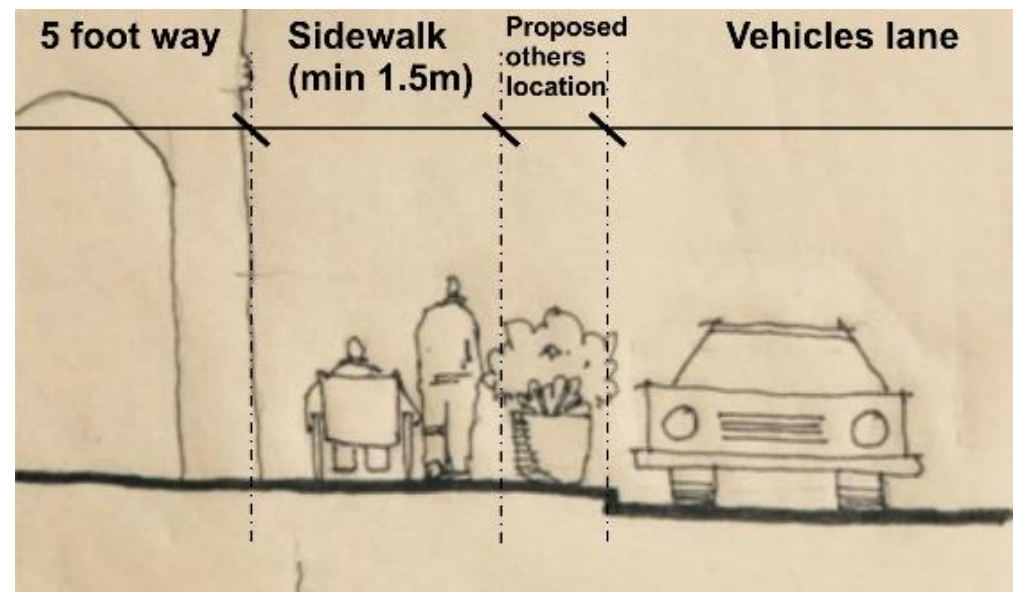

Figure 4.1 Minimum 1.5m width of sidewalk without any obstacle 
PLANNING MALAYSIA:

Journal of the Malaysia Institute of Planners (2017)

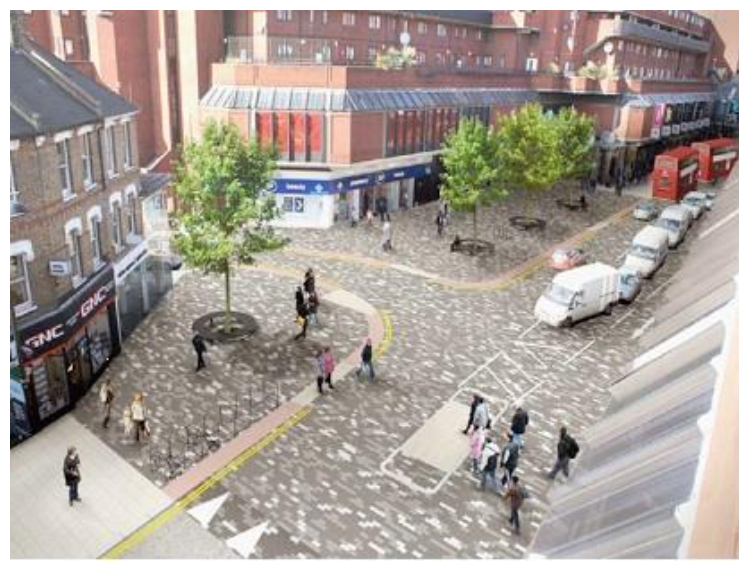

Figure 4.2 An Example of Shared Space Approach

\section{CONCLUSIONS}

This paper has shown that despite the provision of sidewalk in the study area, it is not accessible to PwDs because of the existence of barriers and obstructions on the sidewalk, as well as the design of the sidewalk itself. This paper recommends, among others, the implementation of 'shared space' concept in the study area in order to ensure accessibility to PwDs. At the same time, the access audit which was conducted with actual PwDs proved to be reliable and useful.

\section{ACKNOWLEDGEMENTS}

The authors thank Universiti Kebangsaan Malaysia (UKM) for the support of this research via research grant "GUP 2015-028". Appreciation is also accorded to KAED Universal Design Unit (KUDU) team for their assistance in data collection.

\section{REFERENCES}

Abdul Rahim, A., Zen, I., Abd. Samad, N. A., \& Che Rahim, C. R. (2014). Universal design and accessibility: towards sustainable built environment in Malaysia. In H. Caltenco, P. Hedvall, A. Larsson, K. Rassmus-Grohn \& B. Rydeman (Eds.), Universal Design 2014: Three Days of Creativity and Diversity, Proceedings of the International Conference of Universal Design - Assistive Technology Research Series (Volume 35) (pp. 299-306). Amsterdam: IOS Press.

Bashiti A., \& Abdul Rahim, A. (2015). A study on the accessibility in shopping malls for people with disabilities (PwDs) in Malaysia. International Journal of Natural Science Research, 3(1), 9-20.

Department of Standards Malaysia. (2014). Universal design and accessibility in the built environment - code of practice (2nd revision). Malaysia Standard 1184:2014.

Ja'afar N. H., Sulaiman A. B., \& Shamsuddin, S. (2012). The contribution of landscape features on traditional streets in Malaysia. In M. Y. Abbas, A. F. Ibrahim \& N. 
Nor Haslina Ja'afar, Asiah Abdul Rahim, Nur Amirah Abd. Samad, \& Che Raiskandar Che Rahim

Sidewalk Accessibility at Melaka's Traditional Streets for People with Disabilities (PwDs)

F. Nik Azhari (Eds.), ASEAN Conference on Environment-Behaviour Studies 2012 (pp. 1-14). Bangkok, Thailand: Universiti Teknologi MARA.

Ja'afar N. H. (2015). Karakter fizikal jalan tradisional; kajian kes di Melaka Bandaraya Bersejarah (Doctorate thesis). Universiti Teknologi Malaysia, Skudai, Johor.

Jabatan Kebajikan Masyarakat (2014). Statistik Jabatan Kebajikan Masyarakat 2014.

Harrison, J., \& Dalton, C. (2013). The familiar and the strange: the limits of universal design in the European context. In Proceedings of the $3 \mathrm{rd}$ International Conference on Universal Design in the Built Environment 2013. Kuala Lumpur: KUDU.

Kose, S. (2014). Tourism for all: how can universal/inclusive design accommodate senior travelers? Symposium on Trends in Universal Design 2014, December 1, 2014, Kuala Lumpur, Malaysia.

Lynch, K. (1960). Image of the City. London: The MIT Press.

Mohd Hussain, M. R, Tukiman, I., Zaidin, N., \& Mohd Shahli F. (2016). Campus landscape environment fot student with disabilities (SwDs) in IIUM. Journal of Universal Design in the Built Environment, 2(1), 37-51.

MPMBB. (2010). Rancangan Khas. Majlis Perbandaran Melaka Bandaraya Bersejarah.

Shamsuddin, S., \& Sulaiman, A. B. (2008). Lessons from traditional towns and cities for sustainable future places. In: A. B. Sulaiman \& M. M. Mai (Eds.), Urban design issues in the developing world; the case of Malaysia and Nigeria (pp. 1-174). Kuala Lumpur: Penerbit Universiti Teknologi Malaysia.

Sulaiman, A. B., Shamsuddin, S., \& Anwar, M. (2008). Gentrification process and place attachment in historical settlements: a case study. In Proceeding Regional Architecture and Identity in the Age of Globalization (Vol. 3) (pp. 1287-1298).

Zen, I., Abdul Rahim, A., \& Abu Bakar, A. (2012). Access audit in religious buildings and public spaces in old Damascus city, Syria. Kuala Lumpu: IIUM Press. 
PLANNING MALAYSIA:

Journal of the Malaysia Institute of Planners (2017)

\section{NOTES TO CONTRIBUTORS AND GUIDELINES FOR MANUSCRIPT SUBMISSION}

\section{INTRODUCTION}

The Journal of the Malaysian Institute of Planners or PLANNING MALAYSIA is a multidisciplinary journal related to theory, experiments, research, development, applications of ICT, and practice of planning and development in Malaysia and elsewhere.

The objective of the journal is to promote the activity of town planning through dialogue and exchange of views concerning professional town planning practice. PLANNING MALAYSIA will welcome any news, feature articles, or peer reviewed (including book reviews, software review, etc.) articles for publication. All articles should be original work by the authors. Articles, views and features will not be taken to be the official view of the Malaysian Institute of Planners (MIP) unless it carries the name of MIP as the author. This is to encourage open discussion on diverse issues and opinion for the advancement of town planning practice. Articles and contributions will be accepted from MIP members and non-members worldwide.

In year 2010, PLANNING MALAYSIA Journal has been indexed in SCOPUS. Previous issues of PLANNING MALAYSIA Journal can be viewed on the MIP website.

\section{SUBMISSION OF MANUSCRIPTS}

Manuscript should be emailed to pmjournal@gmail.com. Manuscript should ideally be in the range of 8-10 pages long. Each manuscript should have a title page and an abstract of about 150 words. The title page should contain the title, full name(s), designation(s), organizational affiliation(s), a contact address, and an email address. All manuscripts are received on the understanding that they are not under concurrent consideration at another journal. Exclusive copyright of accepted manuscripts shall be assigned to the Publisher (i.e. the MIP), and in consideration for this, one copy of the current Journal will be provided for each article. Additional reprints of article can be ordered, at cost, by the author(s). PDF format of the article (if available) can be obtained from the Publisher.

\section{LAYOUT}

Manuscript should be typed in single spacing (including footnotes, endnotes and references) on one side of the paper only (preferably A4) with the following margins: right and left $-4.25 \mathrm{~cm}$, top $-5.5 \mathrm{~cm}$ and bottom $-5.2 \mathrm{~cm}$ (including header $-4.5 \mathrm{~cm}$ and footer $-4.3 \mathrm{~cm}$ ) in 11 point Times New Roman font. Footnotes should be numbered consecutively and placed at the end of the manuscript. Footnotes should be kept to a minimum. Tables and diagrams should be provided in the text. References should follow the APA ( $6^{\text {th }}$ Edition) referencing format. All foreign words must be typed and transliterated. The Editorial Board reserves the right to change the transliteration of all historical names, titles and non-English terminology to bring them into conformity with its own style. 


\section{USE OF FORMULA, FIGURES AND TABLES}

Formula (mathematical formula) should be used only when necessary and the conclusions derived must be explained and made intelligible to a non-mathematical reader. Wherever possible, authors are encouraged to place the mathematical parts of the article in an appendix. In cases of empirical articles, authors are expected to make readily available a complete set of data and any specialized computer programs to interested readers.

All illustrations, figures and/or tables in the manuscript must be captioned, in clear black and white (grayscale) and ready for reproduction.

\section{REFEREEING PROCEDURE}

Manuscripts will be acknowledged upon receipt. Only selected (preferred) manuscripts will be reviewed by two (or three) referees in addition to the editors. Editorial decision will normally be made within two to six months, but circumstances beyond control occasionally dictate a longer cycle. If authors are invited to prepare a revision for further consideration, the major issues to be resolved will be outlined and will be forwarded to them as quickly as possible.

\section{ACCEPTED ARTICLES}

Authors of accepted articles will be requested to provide a digital copy of the manuscript, preferably in Microsoft Word to the MIP (the Publisher) via email at pmjournal@gmail.com. MIP will not be responsible for the loss or damage of the digital copy.

\section{COPYRIGHT}

Once published in the PLANNING MALAYSIA, the copyright of the article is automatically vested with the Malaysian Institute of Planners (MIP). The copyright covers the exclusive use of rights to reproduce and distribute the article, including reprints, photographic reproductions, microfilm or any reproduction of a similar nature and translations. Permission to publish illustrations must be obtained by the author before submission. Any acknowledgements should be included in the figure captions.

\section{Contact:}

Editor-in-Chief

PLANNING MALAYSIA

Journal of the Malaysian Institute of Planners

B-01-02, Jalan SS7/13B, Aman Seri, Kelana Jaya,

47301, Petaling Jaya, Selangor Darul Ehsan, MALAYSIA

Tel: +603 78770637 Fax: +60378779636

Email: pmjournal@gmail.com

Homepage: http://www.mip.org.my 


\section{ETHIC STATEMENT}

The Journal of the Malaysia Institute of Planners or PLANNING MALAYSIA is a peerreviewed journal. This statement spells out ethical behaviour of all parties involved in the act of publishing an article for this journal, i.e. the author, the peer-reviewer, the chief editor and editors, and the publisher. This statement is based on COPE's Best Practice Guidelines for Journal Editors. URL: http://publicationethics.org/files/u2 /Best_Practice.pdf

\section{DUTIES OF AUTHORS}

\section{Reporting Standards}

Authors of original research should present an accurate account of the work done as well as an objective discussion of its significance. Data of the research should be represented accurately in the article. An article should contain sufficient detail and references to permit others to replicate the work. Fraudulent or knowingly inaccurate statements constitute unethical behaviour and are unacceptable.

\section{Data Access and Retention}

Authors may be asked to provide the raw data in connection with an article submitted for editorial review, and should be prepared to provide public access to such, if practicable, and should in any event be prepared to retain such data for a reasonable time after publication.

\section{Originality and Plagiarism}

Authors should ensure that they have written entirely original works, and if the authors have used the work and/or words of others this must be appropriately cited or quoted. Such quotations and citations must be listed in the Reference at the end of the article.

\section{Multiple Publication}

An author should not in general publish manuscripts describing essentially the same research in more than one journal or primary publication. Submitting the same manuscript to more than one journal concurrently constitutes unethical publishing behaviour and is unacceptable.

\section{Acknowledgment of Sources}

Proper acknowledgment of the work of others must always be given. Authors should cite publications that have been influential in determining the nature of the reported work.

\section{Authorship of the Paper}

Authorship should be limited to those who have made a significant contribution to the conception, design, execution, or interpretation of the study, and should be listed as coauthors. Others who have participated in certain substantive aspects of the research project, they should be acknowledged or listed as contributors. 


\section{Corresponding Author}

Corresponding author is the author responsible for communicating with the journal for publication. The corresponding author should ensure that all appropriate co-authors and no inappropriate co-authors are included on the paper. All co-authors have seen and approved the final version of the paper and have agreed to its submission for publication.

\section{Acknowledgment of Funding Sources}

Sources of funding for the research reported in the article should be duly acknowledged at the end of the article.

\section{Disclosure and Conflicts of Interest}

All authors should disclose in their manuscript any financial or other substantive conflict of interest that might be construed to influence the results or interpretation of their manuscript.

\section{Fundamental errors in published works}

When an author discovers a significant error or inaccuracy in his/her own published work, it is the author's obligation to promptly notify the journal editor or publisher and cooperate with the editor to retract or correct the paper.

\section{DUTIES OF REVIEWERS}

\section{Contribution of Peer Review}

Peer review assists the chief editor and the editorial board in making editorial decisions while editorial communications with the author may also assist the author in improving the paper.

\section{Unqualified to Review or Promptness}

Any reviewer who feels unqualified to review the assigned manuscript or unable to provide a prompt review should notify the editor and excuse himself/herself from the review process.

\section{Confidentiality}

Manuscripts received for review must be treated as confidential documents. They must not be shown to, or discussed with, others except as authorized by the chief editor. Privileged information or ideas obtained through peer review must be kept confidential and not used for personal advantage.

\section{Standards of Objectivity}

Reviews should be conducted objectively. There shall be no personal criticism of the author. Reviewers should express their views clearly with supporting arguments.

\section{Acknowledgment of Sources}

Reviewers should identify relevant published work that has not been cited by the authors. Any statement that had been previously reported elsewhere should be accompanied by the relevant citation. A reviewer should also call to the chief editor's attention any 
substantial similarity or overlap between the manuscript under consideration and any other published paper of which they have personal knowledge.

\section{Conflict of Interest}

Reviewers should decline to review manuscripts in which they have conflicts of interest resulting from competitive, collaborative, or other relationships or connections with any of the authors.

\section{DUTIES OF EDITORS}

\section{Decision on the Publication of Articles}

The chief editor of the PLANNING MALAYSIA is responsible for deciding which of the articles submitted to the journal should be published. The chief editor may be guided by the policies of the journal's editorial board subjected to such legal requirements regarding libel, copyright infringement and plagiarism. The chief editor may confer with other editors or reviewers in making this decision.

\section{Fair play}

Manuscripts shall be evaluated solely on their intellectual merit.

\section{Confidentiality}

The chief editor/editors and any editorial staff must not disclose any information about a submitted manuscript to anyone other than the corresponding author, reviewers, potential reviewers, other editorial advisers, and the publisher.

\section{Disclosure and conflicts of interest}

Unpublished materials disclosed in a submitted manuscript must not be used by anyone who has a view of the manuscript while handling it in his or her own research without the express written consent of the author. 


\section{PLANNING MALAYSIA JOURNAL: THE PAST ISSUES}

Volume 1, 2003: (http://www.mip.org.my/doc/journal1.pdf)

1. Incorporating Sustainable Development Objectives into Development Plans through Strategic Environmental Assessment Muhammad Faris Abdullah \& Ishak Ariffin

2. Environmental Concern in Local Planning Practice Foziah Johar

3. Ecotourism Planning: Who is Really Responsible? Badarudin Mohammed \& Abdul Aziz. Hussin

4. Towards A Sustainable Built Environment: Environmentally Conscious Planning, Design and Construction Norhayati Mahyuddin

5. Rural Sustainability: An Examination Of The Practice Of Sustainable Development Principles In A Rural Community In Malaysia Ibrahim Ngah

6. Managing Urban Development Process By Using Spatial Information System: A Case Study of I-Space

Alias Abdullah, Muhammad Faris Abdullah \& Fauzan Nordin

7. USM Pushing the Frontier of Town Planning Lee Lik Meng

8. The Suburbanisation of the Kuala Lumpur Metropolitan Region Jamalunlaili Abdullah

Volume 2, 2004: (http://www.mip.org.my/doc/vol.2-2004.pdf)

1. Creating The Essence Of Cities: The Putrajaya's Experience Jebasingam Issace John

2. A Study to Evaluate Child-Friendly Neighbourhoods through a Set of Child-Friendly Indicators

Alias Abdullah \& Nik Munerahanim Nik Muhammad

3. The Evaluation of Beaches in Northern Malaysia Badarudin Mohammed, Rahmat Azam Mustafa, Adrin Abdullah, A. Ghafar Ahmad \& Shida Irwana Omar

4. Urban Land Use Change \& the Langat Basin Ecosystem Health Shaharudin Idrus \& Abdul Samad Hadi

5. Application of Land Use Approaches in Controlling Industrial Wastewater Discharge into River

Muhammad Faris Abdullah

Volume 3, 2005: (http://www.mip.org.my/doc/vol.3-2005.pdf)

1. Planning Education, Accreditation \& Inter-Professional Links Mohd Thalha Alithamby

2. Electronic Local Authority Management System Tan Thean Siew

3. A Study on the Demand of Spatial Planning \& Decision Support System in Malaysia Muhammad Faris Abdullah, Alias Abdullah, Mansor Ibrahim \& Dazilah Abdul Samad

4. The Technology of Asset Management \& Maintenance Culture in Ensuring Sustainable Development

Khairiah Talha \& KC Leong

5. Tessellation Planning \& Honeycomb Housing 
Mazlin Ghazali, Michael J. Durack \& Mohd Peter Davis

6. The Application of the Concept of Defensible Space for Secured Housing Environment Saari Omar \& Megat Arif Shah Megat Omar

Volume 4, 2006: (http://www.mip.org.my/doc/vol.4-2006.pdf)

1. How We Failed To Plan for Habitability Lee Lik Meng, Aldrin Abdullah, Tan Sook Fern, Nurwati Badrulzaman \& Ahmad Sanusi Hassan

2. Cairo's Al-Azhar Park: Millennium Development Goals Etched in Green Khaled el-Khishin

3. Knowledge Cities: Examining the Discourse Smart Villages, Internet Cities Or Creativity Engines Ali A. Alrouf

4. A Preliminary Investigation of A Model On The Decision To Implement Teleworking In The Japanese Business Organisations Abdul Azeez Kadar Hamsa \& Masao Miura

5. An Integration of Multicriteria Analysis with GIS in the Malaysian National Physical Plan Nor Sallehi Kassim \& Rafikul Islam

Volume 5, 2007: (http://www.mip.org.my/doc/vol.5-2007.pdf)

1. Effectiveness of Public Participation Programme: A Feedback from Participants (Sabak Bernam District Local Plan and Kuala Lumpur Structure Plan) Dasimah Omar \& Oliver Ling Hoon Leh

2. Multicriteria Analysis of Flood Causes in Kuala Lumpur Nur Fazzillah Muhamed Noordin, Alias Abdullah \& Muhammad Nur Azraei Shahbudin

3. Urban Housing Development: Town Planning Issues Ibrahim Mohd @ Ahmad, Ezrin Arbi \& Ahmad Ramly

4. Sustainable City Planning: Emphasis on the Management of Environmentally Sensitive Areas Halimaton Saadiah Hashim, Joy Jacqueline Pereira \& Ibrahim Komoo

5. The Environment Component in Sustainability Assessment at the Local Level Plan Abdul Hadi Harman Shah, Shaharudin Idrus \& Abdul Samad Hadi

6. Developing a Communicative Planning Approach to Resolve Land Use Conflicts in Jelutong Area of Georgetown, Penang, Malaysia Mohammad Abdul Mohit \& Raja Mohd. Firdous B. R.M. Harun

7. Komuniti Mapan: Penilaian Tahap Kemapanan Komuniti Orang Asli Temiar Di Negeri Perak

Khairul Hisyam B. Kamarudin \& Ibrahim B. Ngah

8. Book Review: "The Boulevard Book" Shu Charng Yen

Volume 6, 2008: (http://www.mip.org.my/doc/vol.6-2008.pdf)

1. Safe City Programme: Are we on the right path to reduce crime? Kamalruddin bin Shamsudin

2. The Contribution of Fiqh al-Jinayat (Islamic Criminal Law) To the Planning of a Safe City Azila Ahmad Sarkawi, Ahmad Basri Ibrahim \& Alias Abdullah

3. Urban Crime and Safe Neighbourhood: Community Perspectives Khairiah Talha

4. Towards A Safe Place for Children in Today's Residential Neighbourhoods Halimaton Saadiah Hashim, Joy Jacqueline Pereira \& Ibrahim Komoo

5. Role of Land Use Planning in Improving Public Health: Way Forward For Malaysia 
Ainul Jaria Maidin

6. Energy Consumption and Carbon Dioxide Emission Considerations in The Urban Planning Process in Malaysia

Wee Kean Fong, Hiroshi Matsumoto, Chin Siong Ho \& Yu Fat Lun

Volume 7, 2009: (http://www.mip.org.my/doc/journal7.pdf)

1. Urbanization, Environmental Planning and Management: A Challenge for Jamaica. Leiska J. Powell

2. Structural Changes of the Malaysian Economy and Its Spatial Incidence on Regional Economic Growth Mohammad Abdul Mohit

3. Urban Sustainability and Growth Management in South-East Asian City-Regions: The case of Kuala Lumpur and Hong Kong Suharto Teriman, Tan Yigitcanlar, Severine Mayere

4. Urban Sprawl in Malaysia: Evidences from Three Largest Metropolitan Areas Jamalunlaili, Mohd. Zulhafidz Yahaya, Mohd Zuwairi Mod Yunus \& Mohd Shakir Md Ali Safudin

5. An Integrated Approach for the Prediction of Water Quality Index Based on Land Use Attributes Using Data Generation Method and Back Propagation Network Algorithm Faris Gorashi \& Alias Abdullah

6. Groundwater Extraction Modeling for Kuala Lumpur Water Resource Planning Pieter E. Stek

7. Power of the Local Authority in Regulating Land Planning and Development Control: Whither Control Ainul Jaria Maidin \& Bashiran Begum Mobarak Ali

8. Australia Planning Report Card - Telling It Like It Is ! Liz de Chasterl

Volume 8, 2010: (http://www.mip.org.my/doc/vol.8-2010.pdf)

1. Vehicle Ownership and Quality of Life in Urban Residential Neighbourhoods, Northern Peninsular Malaysia Abdul Ghapar Othman \& Hassim Mat

2. Analysis of Commute Characteristics and Residential Location Choice of IIUM Gombak Campus Employees of Malaysia Mohammad Abdul Mohit \& Mootaz Munjid Mustafa

3. The Relationship between Urban Population Density and Transportation Fuel Consumption in Malaysian Cities

Neoh Siew Yin \& Ho Chin Siong

4. The Socio-technical Factors in the Use of GIS at the Planning Departments of the Kuala Lumpur City Hall Mohd Ramzi Mohd Hussain

5. Book Review: Handbook of Research on E-Planning: ICTs for Urban Development and Monitoring, Carlos Nunes Silva (Eds.) IGI Global Publishing Company, Hershey, Pennsylvania, USA (2010). 454 pages. ISBN-13:9781615209293.

Alias Abdullah \& Carlos Nunis Silva

Volume 9, 2011: (http://www.mip.org.my/doc/vol9.pdf)

1. City Development Strategies (CDS) Contribution toward Sustainable Urban Development in Developing Countries

S. Mostafa Rasoolimanesh, Nurwati Badarulzaman \& Mastura Jaafar

2. Urban Residents' Attitude toward Wildlife in Their Neighbourhoods: The Case Study of Klang Valley, Malaysia 
PLANNING MALAYSIA:

Journal of the Malaysia Institute of Planners (2017)

Nik Hanita Nik Mohamad

3. Evaluating Stakeholders' Preferences: Reconciling Heritage And Sustainability In Kuala Lumpur Traditional Area Noor Amila Wan Abdullah Zawawi \& Alias Abdullah

4. Solid Waste Generation Characteristics: The Malaysia Local Authorities' Outlook Muhammad Abu Eusuf, Mansor Ibrahim, Shamzani Affendy Mohd. Din \& Rafikul Islam

5. Urban Air Environmental Health Indicators: A Preliminary Set for City of Kuala Lumpur Oliver Ling Hoon Leh, Shaharuddin Ahmad Kadaruddin Aiyub \& Yaakob Mohd. Jani

6. Classification of Satellite Fused Data for Land Use Mapping in Development Plan Norzailawati Mohd Noor, Alias Abdullah \& Mazlan Hashim

Special Issue I, 2011: (http://www.mip.org.my/doc/MIP\%20Jurnal\%20Special\%20Issue\%20on\%20Langkawi. pdf)

1. Conservation with Development: Showcasing Langkawi Geopark - An Introduction Halimaton Saadiah Hashim \& Rahimah Abdul Aziz

2. Geopark for Heritage Conservation: A Need for Integrated Planning and Management Rahimah Abdul Aziz, Halimaton Saadiah Hashim, \& Ibrahim Komoo

3. Implementing Langkawi Geopark through Land Use Planning Noor Yazan Zainol, Hapiz Abd Manap, Ibrahim Yacob, Mahani Muhammad, Mariam Tajuddin \& Ikhwan Mohd Said

4. The Importance of Geological Heritage Resources in Land Use Planning: Experience from Langkawi Geopark Che Aziz Ali \& Tanot Unjah

5. Land Use Planning Statutes for Langkawi Geopark Conservation and Development Sarah Aziz, Halimaton Saadiah Hashim, Rahimah Abdul Aziz, Chan K. L. Geraldine \& Tanot Unjah

6. Potential Biosites of Significant Importance in Langkawi Geopark: Terrestrial Vertebrate Fauna

Norhayati, A., Chan, K.O., Daicus, B., Samat, A.,Grismer, L.L, \& Mohd Izzuddin, A.

7. Planning for Heritage Tourism: The Case of Langkawi Geopark Ong Puay Liu \& Sharina Abd Halim

8. Place Making, Place Names, and Local Myths and Legends Rahimah Abdul Aziz \& Ong Puay Liu

9. Introducing Networks in Planning: An Example from Langkawi Chan K. L. Geraldine, Halimaton Saadiah Hashim \& Sarah Aziz

10. Participation towards Heritage Conservation: Case of a Fishing Community in Langkawi Geopark Sharina Abdul Halim, Ong Puay Liu, Nurhafizah Yussof \& Lim Choun Sian

Volume 10, 2012: (http://www.mip.org.my/doc/vol.10-2012.pdf)

1. Determinant Factors of Neighbourhood Quality Norainah Abdul Rahman, Dasimah Omar \& Abdul Ghani Salleh

2. The Relationship between Variations of Grid Layout and Burglary Saniah Ahmad Zaki \& Jamalunlaili Abdullah

3. Analysis of Factors Influencing the Stated Preference of Academic Employees towards Telecommuting in IIUM Campus, Gombak Farah Diyanah Ismail, Abdul Azeez Kadar Hamsa \& Mansor Ibrahim

4. Study on the Potential of Urban Forest Park for Sustainable City Noralizawati Mohamed, Noriah Othman \& Mohd Hisham Ariffin 
5. A Study on the Effectiveness of Provision of New Static Information Signage: A Case Study of International Islamic University Malaysia, Gombak Campus

Syazwani Sahrir, Syahriah Bachok \& Mariana Mohd. Osman

6. Study the Construction and Demolition Wastes in Klang Valley, Malaysia

Muhammad Abu Eusuf, Mansor Ibrahim \& Rafikul Islam

7. The Future of Coastal Management Programme in Malaysia: Making the Coast Visible to Planners

M. Zainora Asmawi

Special Issue II, 2013: (http://www.mip.org.my/doc/se2013.pdf)

1. Impacts of Urban Land Use on Crime Patterns through GIS Application Ahmad Nazri Muhamad Ludin, Norsiah Abd. Aziz, Nooraini Hj Yusoff \& Wan Juliyana Wan Abd Razak

2. Estimation of Residential Impervious Surface using GIS Technique M. Rafee Majid, Jamal Aimi Jamaludin \& Wan Yusryzal Wan Ibrahim

3. Green Space Audits on its Accessibility in Pasir Gudang

Wan Yusryzal Wan Ibrahim, Ahmad Long \& Ariva Sugandi Permana

4. Firm Dynamic Analysis for Urban Land Use and Economic Growth Modelling Noordini Che' Man, Soheil Sabri, Nafisa Hosni \& Harry Timmermans

5. Assessment of Neighbourhood Affordability based on Housing and Transportation Costs in Kuala Lumpur, Malaysia

Soheil Sabri, Ahmad Nazri M. Ludin \& Foziah Johar

6. Potential Urban Development Parameters that Reduce Energy Consumption in Residential Area Ariva Sugandi Permana, Norsiah Abd. Aziz \& Abd. Razak Jaffar

7. Incorporating Pedestrian Index into Googlemaps Nabila Abdul Ghani, Muhammad Zaly Shah Muhammad Hussein \& Safizahanin Mokhtar

8. Seismic Microzonation for Banda Aceh City Planning Foziah Johar, M. Rafee Majid, Abdul Razak Jaffar \& Adi Safyan Yahya

9. The Reliability Test of Visual Landscape Features Measurement in Highlands Tourism Planning Nafisa Hosni, Nooraini Yusoff \& Hairul Nizam Ismail

Volume 11, 2013: (http://www.mip.org.my/doc/Journal\%202014.pdf)

1. Malaysian Development Plan System: Issues and Problems, One Decade after its Reform (2001-2011)

Faizah Ahmad, Ibrahim Mohd., Syra Lawrance Maidin, Rosilawati Zainol \& Norzailawati Mohd Noor

2. Perceptions on Quality of Life in Malaysia: The Urban-Rural Divide Norhaslina Hassan, Noor Ismawati Mohd Jaafar, Raja Noriza Raja Ariffin, Asnarulkhadi Abu Samah \& Mohd Nazari Jaafar

3. Awareness by Kuala Lumpur City Hall Staffs for Successful Implementation of Crime Prevention through Environmental Design (CPTED)

Shuhana Shamsuddin \& Natasha Azim Hussin

4. Sustainable Forest Management in Lower Kinabatangan, Sabah: Issues and Current Practices

Normah Abdul Latip, Nurwati Badarulzaman, Azizan Marzuki \& Mohd Umzarulazijo Umar

5. User's Preference and Perception on the Pedestrian Crossing in Malaysia: The Case of Ampang Road, Kuala Lumpur 
Oliver Ling Hoon Leh, Zamila Zamri, Mohd Zamreen Mohd Amin \& Marlyana Azyyati Marzukhi

6. Commuters' Perceptions on Rail based Public Transport Services: A Case Study of KTM Komuter in Kuala Lumpur City, Malaysia

Syahriah Bachok, Mariana Mohamed Osman, Ummi Aqilah Khalid \& Mansor Ibrahim

7. Land Cover Change Detection Analysis on Urban Green Area Loss Using GIS and Remote Sensing Techniques

Norzailawati Mohd Noor, Alias Abdullah \& Mohd Nasrul Hanis Manzahari

8. Analysis of Factors Influencing Use of Motorcars in International Islamic University Malaysia

Nelza Lynna Abdul Rahim \& Abdul Azeez Kadar Hamsa

Volume 12, 2014: http://www.mip.org.my/doc/Journal12.pdf

1. Evaluating the Impact of Density on Access to Local Facilities in Urban Neighbourhoods Wan Nurul Mardiah Wan Mohd Rani

2. Town Planners' Perceptions of Sports Facilities and Urban Development: A Case Study of 13 States' Main Sports Facilities in Malaysia

Maassoumeh Barghchi \& Dasimah Bt Omar

3. Disaster Risk Reduction In Malaysian Urban Planning Intan Afida Mohamad Amin \& Halimaton Saadiah Hashim

4. Conceptualise Tourism Support System through Web-Based GIS for Collaborative Tourism Planning

Tarmiji Masron, Azizan Marzuki, Badaruddin Mohamed \& Norizawati Mohd Ayob

5. Integrating Climate Change Mitigation and Adaptation into Spatial Planning: Developing Criteria for Spatial Plan Evaluation in the Selangor River Basin Chee Ping Ngang, Joy Jacqueline Pereira \& Halimaton Saadiah Hashim

6. Analysis on Community Involvement in Cultural Activities: Transmission of Ethnic Language

Aisyah Abu Bakar, Mariana Mohamed Osman, Syahriah Bachok \& Mansor Ibrahim

Special Issue III, 2014: (http://www.mip.org.my/doc/JournalSE3.pdf)

1. Geospatial Technology Approaches in Urban Morphology for Resilient Urban Governance

Norzailawati binti Mohd Noor, Marina Mohd Nor, Alias Abdullah \& Rustam Khairi Zahari

2. Sustainable Governance in relation to the Financial Aspect in Managing Coastal Areas: Malaysian Experience

M.Zainora Asmawi, Lukman Hakim Mahamod, Mohd Zin Mohamed \& Tuminah Paiman

3. E-payment at the Local Government Level: A Study of Majlis Bandaraya Shah Alam and Majlis Daerah Kampar

Rustam Khairi Zahari, Raja Noriza Raja Ariffin, Nurhawani Zamin \& Norzailawati binti Mohd Noor

4. Residential Satisfaction -Concept, Theories \& Empirical Studies Mohammad Abdul Mohit \& Adel Mahfoud Mubarak Al-Khanbashi

5. Historical Influences to Present Legal Setting of Planning Law in Malaysia Azila Ahmad Sarkawi \& Muhammad Faris Abdullah

6. Understanding of Tourists' Preferences Pattern: A Study in Melaka,Malaysia Syakir Amir, Mariana Mohamed Osman, Syahriah Bachok \& Mansor Ibrahim

7. The Review for the Use of Urban Climatic Map in the Land Use Plan for Urban Planning Illyani Ibrahim, Azizan Abu Samah \& Rosmadi Fauzi 
8. Evaluating the Effects of Road Geometrical Design Towards Spot Speed Distribution on Arterial Road

Noor Hafiza Mohd Maksid \& Abdul Azeez Kadar Hamsa

Volume 13, 2015: (http://www.mip.org.my/doc/PMJ2015.pdf)

1. Creative Cities Research in Penang, Malaysia: A Review of Conceptual and Methodological Framework

Khoo Suet Leng, Nurwati Badarulzaman, Narimah Samat, Morshidi Sirat \& Sharifah

Rohayah Sheikh Dawood

2. The Role of Fabric Banners for Community Engagement in Digital Era

Rosilawati Zainol, Goh Hong Ching, Ibrahim Mohd, Nikmatul Adha Nordin, Siti

Maisara Baharom \& Tengku Adeline Adura Tengku Hamzah

3. Thermal Comfort and Energy Solutions for a Better Residential Environment in Malaysia

Noor Aziah Mohd Ariffin

4. The Relationship of Human Happiness and Neighbourhood Planning: Case Study Puchong Indah Housing Estate, Selangor, Malaysia

Oliver Ling Hoon Leh, Farah Ayuni Marhalim, Siti Nur Afiqah Mohamed Musthafa, Yusfida Ayu Abdullah \& Marlyana Azyyati Marzukhi

5. Assessing the Urban and Rural Stage Bus Services Disparities in Peninsula Malaysia Zakiah Ponrahono, Syahriah Bachok, Mariana Mohamed Osman, Mansor Ibrahim, Muhammad Faris Abdullah \& Alias Abdullah

6. The Roles of Urban Heritage in Determining the Image of the Royal Town of Sri Menanti, Negeri Sembilan

Nor Zalina Harun, Dg. Norhidayah Fairuz \& Nor Adilla Nordin

7. Carbon Sequestration through Urban Green Reserve and Open Space Alamah Misni, Sakurah Jamaluddin \& Siti Mazwin Kamaruddin

8. Sustainable Governance in Relation to the Financial Aspect in Managing Coastal Areas: Malaysian Experience

M.Zainora Asmawi, Lukman Hakim Mahamod, Mohd Zin Mohamed, \& Tuminah Paiman

\section{Special Issue IV, 2016: http://www.mip.org.my/doc/apsa2016.pdf}

1. Mapping Poverty Hot Spots in Peninsular Malaysia Using Spatial Autocorrelation Analysis

M. Rafee Majid, Abdul Razak Jaffar, Noordini Che Man, Mehdrad Vaziri \& Mohamed Sulemana

2. Managing Urbanisation and Urban Sprawl in Malaysia by Using Remote Sensing and GIS Applications

Nur Aulia Rosni, Norzailawati Mohd Noor \& Alias Abdullah

3. From Trade Routes to Streets Cultures - An Overview of the Significance and Characteristics of Southeast Asian Traditional Streets

Mongkol Khan \& Syed Zainol Abidin Idid

4. Leadership Styles: Incentive or Disincentive Approach in Addressing Street Vendor Problems in Jakarta and Bandung, Indonesia Ariva Sugandi Permana, Norsiah Abd Aziz \& Ho Chin Siong

5. Preservation of Urban Cultural Landscape: Case Study of Roji in Kagurazaka, Tokyo Benika Morokuma

6. Community Perception of Management Goals in Matoushan National Nature Reserve Chengzhao Wu, Tianren Yang, Pei Pei \& Haisu Chen

7. Tripographic Assessment of VFR Travel in Context of Malaysian Domestic Travelers 
Sharifah Eisyahtun Syed Darar \& Hairul Nizam Ismail

8. Evaluating Significant Factors that Influence Public Transport Usage in Kerman, Iran Azin Bahreini, Hamed Mirzaei, Mehdi Moeinaddini, Zohreh Asadi-Shekari, Muhammad Zaly Shah \& Zahid Sultan

9. Influences of Housing Settings and Designs in Fulfilling the Malay Residents' Social Cultures

Noor Aimran Samsudin \& Syed Zainol Abidin Idid

10. The Impact of Iskandar Malaysia Development on Urban Amenities Muhammad Rafeq Razak, Foziah Johar \& Rabiatul Adawiyah Abd Khalil

11. Factor Analysis of Motorcycle Crashes in Malaysia Zahid Sultan, Noor Irdiana Ngadiman, Fara Dela A.Kadir, Nuur Fathin Roslan \& Mehdi Moeinaddini

12. An Overview of Critical Success Factors of Public-Private Partnership in the Delivery of Urban Infrastructure and Services

Zayyanu Muhammad, Kim Kwang Sik, Foziah Johar \& Soheil Sabri

13. The Provision of Vertical Social Pockets for Better Social Interaction in High-Rise Living Siew Bee, Aw \& Poh Im, Lim

14. The Rukun Warga-Based 3Rs and Waste Bank as Sustainable Solid Waste Management Strategy

Sherly Towolioe, Ariva Sugandi Permana \& Norsiah A. Aziz, Chin Siong Ho \& Dario G. Pampanga

15. Liveability Planning for Cities: Within the Islamic Framework of Maqasid Al-Shari'ah Norimah Md Dali, Alias Abdullah \& Azila Ahmad Sarkawi

16. Islamisation of Town Planning Education: A Review on the Courses Offered by the Department of Urban and Regional Planning, International Islamic University Malaysia Azila Ahmad Sarkawi, Alias Abdullah \& NorimahMd Dali

17. Spatiotemporal Land Use and Land Cover Change in Major River Basins in Comprehensive Development Area

Wan Yusryzal Wan Ibrahim \& Ahmad Nazri Muhamad Ludin

18. Human Behaviour in Open Space around Spring Water in a Central Area of Mito-City in Japan

Takayuki Kumazawa

19. Identify Significant Indicators for a Happy City

Hamed Mirzaei, Azin Bahreini, Mehdi Moeinaddini, Zohreh Asadi-Shekari, Muhammad Zaly Shah \& Zahid Sultan

20. A Discrete Choice Model for Firm Location Decision Noordini Che' Man \& Harry Timmerman

21. Co-Benefit Modelling and Optimization of Air Pollution Control in Iskandar Malaysia: A Methodology using BenMAP

Nadhirah Nordin, M. Rafee Majid, Ho Chin Siong \& Gakuji Kurata

22. Exploring the Implementation and Success of Green Urban Mobility in Asian Cities Zahid Sultan, Nuhu H. Tini \& Mehdi Moeinaddini

23. Analysis of Shrines Properties using Remote Sensing Approach: Case Study of Lembah Bujang

Shairatul Akma Roslan, Norzailawati Mohd Noor, Alias Abdullah \& Zuraini Md Ali

24. The Evolvement of Brand Identity of Langkawi Island, Malaysia Mohd Fadil Mohd Yusof \& Hairul Nizam Ismail

25. A Theoretical Overview of Road Hump Effects on Traffic Speed in Residential Environments

Khairun Sarah Radhiah Bachok, Abdul Azeez Kadar Hamsa, Mohd Zin Mohamed \& Mansor Ibrahim 
26. Implications of Sprawled and Compact Development on Mobility Patterns: A Case-Study of Bhopal, India

Neha Saxena \& Chidambara

27. Research for a Comprehensive and Active Planning Method in an Industrial-Residential Mixed Area- Focused on Ota Creative Town Vision in Ota Ward, Tokyo

Taku Nohara, Yu Okamura \& Susumu Kawahara

28. Measuring the Dimensions and Attributes of Liveability of Low-Income Housing Communities in Nigeria

Sule Abass Iyanda \& Mohammad Abdul Mohit

29. An Investigation on the Relationship between Land Use Composition and PM10 Pollution in Iskandar Malaysia

Muhammad Azahar Zikri Zahari, M. Rafee Majid, Ho Chin Siong, Gakuji Kurata \& Nadhirah Nordin

30. Monitoring the Performance of State Structure Plan in Delivering Output using Dynamic Model

Muhammad Faris Abdullah, Alias Abdullah, Rustam Khairi Zahari \& Samsuddin Jaafar

Special Issue $V$, 2016:

1. Sustainable Urban Development Through Urban Consolidation Policy in Shiraz, Iran Mozhgan Samzadeh, Zunaibi Abdullah, Saari Omar \& Aniza Abdul Aziz.

2. An Initiatives-Based Framework for Assessing Smart City

Yasmin Mohd Adnan, Hasniyati Hamzah, Melasutra Md Dali, Md Nasir Daud \& Anuar Alias

3. Environmental Psychology: The Urban Built Environment Impact On Human Mental Health

Chen Wang, Suzaini M. Zaid \& Nurhanisah Nazarali

4. Demographic Transition and Sustainable Communities in Malaysia

Hanan Elsawahli, Faizah Ahmad \& Azlan Shah Ali

5. Elderly and Community Health Care Facilities: A Spatial Analysis

Rosilawati Zainol \& Christopher J. Pettit

6. Sustainable Housing Affordability in Sabah

Rosli Said, Rohayu Ab. Majid, Anuar Alias, Yasmin Mohd Adnan \& Muhammad Najib Razali

7. The Challenge of Labour Shortage for Sustainable Construction

Faizul Azli Mohd-Rahim, Nurul Safwah Mohd-Yusoff, Wang Chen, Nurshuhada Zainon \& Rafikullah Deraman

8. Incorporating Walking in Travel to Work: The Meaning of Commuting for Kuala Lumpur Community

Mastura Adam \& Ahmed Abubakar

9. Campus Walkability in Malaysian Public Universities: A Case-Study of Universiti Malaya

Liow Ken Keat, Naziaty Mohd Yaacob \& Nor Rasidah Hashim

10. Prevention of Aedes Breeding Habitats for Urban High-Rise Building in Malaysia Nurshuhada Zainon, Faizul Azli Mohd Rahim, Dalila Roslan \& Azlan Helmy Abd-Samat

11. Energy Efficiency Policy for Existing Typical Campus Buildings in The University of Malaya

Muhammad Azzam Ismail, Karam M. Al-Obaidi, Raha Sulaiman

12. Preferences of Student Residents Towards Sustainability with The Concept of Bioclimatic Design

Adi Ainurzaman Jamaludin, Hazreena Hussein, Nila Keumala \& Ati Rosemary Mohd Ariffin 
PLANNING MALAYSIA

Journal of the Malaysia Institute of Planners (2017)

13. Synthesising an Effective Incentives System in Safeguarding the Heritage Village of Melaka and George Town

Indera Syahrul Mat Radzuan \& Yahaya Ahmad

Volume 14, 2016:

1. Main Criteria in the Development of Smart Cities Determined using Analytical Method Zurinah Tahir \& Jalaluddin Abdul Malek

2. Understanding Land Idling as a Strategic Behaviour: A Brief Note Using the Real Options Approach

\section{Haniza Khalid}

3. Sustainable Well-Being: An Empirical Exploration on Human Needs and Human Interdependency

Aisyah Abu Bakar, Mariana Mohamed Osman, Syahriah Bachok, Mansor Ibrahim \& Muhammad Faris Abdullah

4. Information Quality for Flood Risk Reduction in Site Planning: Town Planners' Perception Intan Afida, Shaharudin Idrus \& Halimaton Saadiah Hashim

5. A Study on the Effects of Road Humps in Reducing Speed Along Local Roads in Residential Areas: Case Study of Taman Setiawangsa Siti Syazwani Ahmad Sofi \& Abdul Azeez Kadar Hamsa

6. What Brings Youth to Recreational Park?

Rosilawati Zainol \& Cheong Peng Au-Yong

7. Neighbourhood Satisfaction and Qoul in Middle-Income Housing in Kuala Lumpur City, Malaysia

Mohammad Abdul Mohit \& Mohamed Sajid Ali

8. Identifying Factors Influencing Urban Spatial Growth for the George Town Conurbation Mohd Amirul Mahamud, Narimah Samat \& Norzailawati Mohd Nor

9. The Critiques to Positivism Direction of Inquiry in Comprehending the Complexity of Governance in Managing Cities Competitiveness

Faizul Abdullah \& Fatimah Yusof 